\title{
Review \\ Paving the Way for a Green Transition in the Design of Sensors and Biosensors for the Detection of Volatile Organic Compounds (VOCs)
}

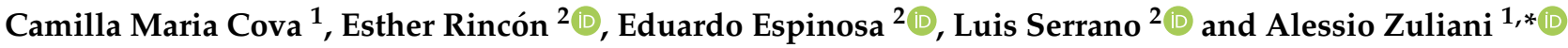 \\ 1 Department of Chemistry, University of Florence and CSGI, Via della Lastruccia 3, \\ 50019 Sesto Fiorentino, FI, Italy; cova@csgi.unifi.it \\ 2 BioPren Group, Inorganic Chemistry and Chemical Engineering Department, Faculty of Sciences, \\ University of Cordoba, 14014 Cordoba, Spain; b32rirue@uco.es (E.R.); eduardo.espinosa@uco.es (E.E.); \\ iq3secal@uco.es (L.S.) \\ * Correspondence: zuliani@csgi.unifi.it
}

check for updates

Citation: Cova, C.M.; Rincón, E.; Espinosa, E.; Serrano, L.; Zuliani, A. Paving the Way for a Green Transition in the Design of Sensors and Biosensors for the Detection of Volatile Organic Compounds (VOCs) Biosensors 2022, 12, 51. https:// doi.org/10.3390/bios12020051

Received: 27 December 2021

Accepted: 18 January 2022

Published: 19 January 2022

Publisher's Note: MDPI stays neutral with regard to jurisdictional claims in published maps and institutional affiliations.

Copyright: (C) 2022 by the authors. Licensee MDPI, Basel, Switzerland. This article is an open access article distributed under the terms and conditions of the Creative Commons Attribution (CC BY) license (https:// creativecommons.org/licenses/by/ $4.0 /)$.

\begin{abstract}
The efficient and selective detection of volatile organic compounds (VOCs) provides key information for various purposes ranging from the toxicological analysis of indoor/outdoor environments to the diagnosis of diseases or to the investigation of biological processes. In the last decade, different sensors and biosensors providing reliable, rapid, and economic responses in the detection of VOCs have been successfully conceived and applied in numerous practical cases; however, the global necessity of a sustainable development, has driven the design of devices for the detection of VOCs to greener methods. In this review, the most recent and innovative VOC sensors and biosensors with sustainable features are presented. The sensors are grouped into three of the main industrial sectors of daily life, including environmental analysis, highly important for toxicity issues, food packaging tools, especially aimed at avoiding the spoilage of meat and fish, and the diagnosis of diseases, crucial for the early detection of relevant pathological conditions such as cancer and diabetes. The research outcomes presented in the review underly the necessity of preparing sensors with higher efficiency, lower detection limits, improved selectivity, and enhanced sustainable characteristics to fully address the sustainable manufacturing of VOC sensors and biosensors.
\end{abstract}

Keywords: biosensors; VOCs; environmental; packaging; diagnostic; pollution

\section{Introduction}

The United States Environmental Agency (EPA) and the European Environmental Agency (EEA) define as a volatile organic compound (VOC) any organic substance that under normal conditions is gaseous or can vaporize in the atmosphere [1,2]. Although this general description helps in easily recognizing a volatile organic compound, it is too rough and is not unequivocal in identifying VOCs. Therefore, different national and international regulations have proposed more standardized definitions according to selected physico-chemical properties of the considered chemicals. Among all, the EU Council Directive 1999/13/EC (and successive amendments and corrections) indicates as a VOC "any organic compound having at $20^{\circ} \mathrm{C}$ a vapor pressure of $0.01 \mathrm{kPa}$ or more or having a corresponding volatility under the particular conditions of use" [3]. Additionally, the quite dated-although still highly cited in the literature [4] - 1989 World Health Organization's (WHO) definition classifies as a VOC any organic chemical having a boiling point up to $250{ }^{\circ} \mathrm{C}$ measured at a standard atmospheric pressure of $101.3 \mathrm{kPa}$. Based on this definition, the WHO subdivided VOCs into different classes: very volatile organic compounds, VVOCs, having boiling points ranging from $<0{ }^{\circ} \mathrm{C}$ to $50-100{ }^{\circ} \mathrm{C}$, such as propane $\left(\mathrm{C}_{3} \mathrm{H}_{8}\right)$, butane $\left(\mathrm{C}_{4} \mathrm{H}_{10}\right)$, methyl chloride $\left(\mathrm{CH}_{3} \mathrm{Cl}\right)$; and volatile organic compounds, VOCs, with boiling points in the range from $50-100{ }^{\circ} \mathrm{C}$ to $240-260{ }^{\circ} \mathrm{C}$, including substances such as formaldehyde $\left(\mathrm{CH}_{2} \mathrm{O}\right)$, limonene $\left(\mathrm{C}_{10} \mathrm{H}_{16}\right)$, and ethanol $\left(\mathrm{C}_{2} \mathrm{H}_{5} \mathrm{OH}\right)$. The WHO also defined an additional category of semi-volatile organic compounds, SVOCs, including substances 
having boiling points ranging from $240-260^{\circ} \mathrm{C}$ to $380-400{ }^{\circ} \mathrm{C}$, such as some pesticides like dichlorodiphenyltrichloroethane (DDT), chlordane or some plasticizers like phthalates [5].

Without going deeper into the merits of the diverse definitions of VOCs, schematically summarized into Figure 1, it is quite glaring that all of them align in proving the abundance of organic chemicals identifiable as volatile in many different types of environments.

\begin{tabular}{|l|c|c|}
\hline $\begin{array}{l}\text { UNITED STATES ENVIRONMENTAL AGENCY } \\
\text { and }\end{array}$ & WORLD HEALTH ORGANIZATION \\
EUROPEAN ENVIRONMENTAL AGENCY & EU COUNCIL DIRECTIVE 1999/13/EC \\
$\begin{array}{c}\text { Any organic substance that under normal } \\
\text { conditions is gaseous or can vaporize in the } \\
\text { atmosphere }\end{array}$ & $\begin{array}{c}250^{\circ} \mathrm{C} \text { measured at a standard atmospheric } \\
\text { pressure of } 101.3 \mathrm{kPa} \text {. }\end{array}$ & $\begin{array}{c}\text { Any organic compound having at } 20^{\circ} \mathrm{C} \text { a vapor } \\
\text { pressure of } 0.01 \mathrm{kPa} \text { or more or a corresponding } \\
\text { volatility under the conditions of use }\end{array}$ \\
\hline
\end{tabular}

Figure 1. Definition of VOCs according to the United States Environmental Agency (EPA) and the European Environmental Agency (EEA), the World Health Organization (WHO) and the EU Council Directive 1999/13/EC.

Benzene $\left(\mathrm{C}_{6} \mathrm{H}_{6}\right)$, toluene $\left(\mathrm{C}_{7} \mathrm{H}_{8}\right)$, ethyl benzene $\left(\mathrm{C}_{8} \mathrm{H}_{10}\right)$, ortho-, meta- and para-xylene, (known as BTEX) $\left(\mathrm{C}_{8} \mathrm{H}_{10}\right)$, acetone $\left(\mathrm{C}_{3} \mathrm{H}_{6} \mathrm{O}\right)$, styrene $\left(\mathrm{C}_{8} \mathrm{H}_{8}\right)$, and benzyl alcohol $\left(\mathrm{C}_{7} \mathrm{H}_{8} \mathrm{O}\right)$, are just a few examples of commonly known organic substances having vapor pressure values higher than $0.01 \mathrm{kPa}$ at $20^{\circ} \mathrm{C}$ and / or boiling points below $250^{\circ} \mathrm{C}$, that must therefore be considered as VOCs. These substances may be found in ordinary home indoor sites, and in other countless indoor and outdoor environments (and microenvironments) such as those located in industries [6], commercial places [7], hospitals [8], schools [9], etc. For example, among the most diffused VOCs in homes, during the analysis of the inner air of 5000 houses in Japan, acetaldehyde $\left(\mathrm{C}_{2} \mathrm{H}_{4} \mathrm{O}\right)$, toluene, and formaldehyde were found to be the most abundant VOCs [10]. In another study, the analysis of the inner air in art and craft rooms as well as in common class rooms in a primary school showed mainly the presence of benzyl alcohol, styrene, toluene, ethylbenzene $\left(\mathrm{C}_{8} \mathrm{H}_{10}\right)$, and xylene [11].

In general, VOCs may be emitted from countless sources, such as furnishing items, building materials, lavatory and laundry products, and biological matter (such as food), etc. [12,13]. For instance, the presence has been observed of a considerably high amount of toxic formaldehyde in a sealed room containing commonly employed, medium-density fiberboards [14], and a sensibly increased concentration of toluene was proved in kitchens during dishwasher washing cycles [15].

Different environments imply the presence of different VOCs, and which varieties and their corresponding concentrations are not only determined and influenced by the materials from which they are emitted, but also from the atmospheric conditions, such as temperature or relative humidity [16], the presence of other materials which may act as adsorbers of VOCs $[17,18]$, the rate of air flux/ventilation [19], and the presence and intensity of visible light/UV irradiation [20], etc. Thus, it is not possible to tabulate general average concentration values of VOCs in the function of similar environments; however, based on numerous studies reported in the literature, it is achievable to draw up lists of VOCs more likely emitted from specific sources and materials in determined situations [21,22]. For example, besides the recognizable emission of VOCs in chemical industries traceable to the mere pure substances [23], it is well known that cellulosic materials such as wood or paper emit acetic and formic acid due to the hydrolysis of acetyl group esters in hemicellulose [24]. Additionally, a large number of polymeric materials used in consumer goods such as furnishings [25], artificial leather or building materials, emit certain VOCs. Bis(2-ethylhexyl)phthalate (DEHP), a plasticizer with significant health concerns, is emitted from poly(vinyl chloride) (PVC) [26], while styrene, recognized as cancerogenic, is emitted from degraded polystyrene (PS) [27]. 
Cities and high-traffic areas are especially polluted by VOCs emitted from the use of motor vehicle fuels (considering both fuel evaporation and exhaust gas) [28,29], such as toluene, benzene or heptane $\left(\mathrm{C}_{7} \mathrm{H}_{16}\right)$ [30].

Some specific VOCs are also emitted during food processing as well as during food degradation while 1-butanol $\left(\mathrm{C}_{4} \mathrm{H}_{10} \mathrm{O}\right)$, 1-hexanol $\left(\mathrm{C}_{6} \mathrm{H}_{14} \mathrm{O}\right)$, 2-ethyl-hexanol $\left(\mathrm{C}_{8} \mathrm{H}_{18} \mathrm{O}\right)$ and some volatile fatty acids, such as butyric $\left(\mathrm{C}_{4} \mathrm{H}_{8} \mathrm{O}_{2}\right)$, valeric $\left(\mathrm{C}_{5} \mathrm{H}_{10} \mathrm{O}_{2}\right)$ or caproic $\left(\mathrm{C}_{6} \mathrm{H}_{12} \mathrm{O}_{2}\right)$ acids, are produced during the spoilage of meat, fish, or fruit, or more generally during the decomposition, i.e., anaerobic digestion, of biomass [31].

Many plants and flowers also emit specific VOCs. Actually, phytogenic volatile organic compounds (PVOCs) represent the most abundant VOCs present in the atmosphere [32] What we recognize as natural perfumes and fragrances capable of stimulating our senses causing an upsurge of sensations and feelings, are nothing but VOCs. For example, cinnamyl alcohol $\left(\mathrm{C}_{9} \mathrm{H}_{10} \mathrm{O}\right)$, having an intense smell of sweet hyacinth with balsamic and spicy notes, is a VOC found in cinnamon leaves and flowers [33]. Citronellol $\left(\mathrm{C}_{10} \mathrm{H}_{20} \mathrm{O}\right)$, smelling rosy, sweet and of citrus, is a monoterpenoid VOC principally found in roses and pelargonium flowers [34]. These substances are mainly released by flowers to attract pollinators, while other natural VOCs, such as isoprenoids, are naturally released by plants to improve resistance in response to abiotic stresses [35,36].

Many other biological and microbiological processes also imply the release of characteristic VOCs $[37,38]$. Among them, VOCs emitted by microorganisms (i.e., bacteria, archaea, fungi, and protists) are specifically classified as Microbial Volatile Organic Compounds (MVOCs) and comprise a large variety of chemicals such as fatty acids and their derivatives, nitrogen- and sulfur-containing compounds, aromatics and terpenoids $[39,40]$. Other VOCs are emitted in the biological processes occurring in human bodies [41-43]. For example, it has been observed that breath samples from breast cancer patients contain a unique combination of hydrocarbons, such as alkanes and monomethylated alkanes $[44,45]$.

Hundreds of different VOCs are thus diffused and present in an infinite number of environments whether deriving from degradation processes, biological processes, natural events, or human activities such as industrial productions, transportation, etc. Consequently, the detection and quantification of VOCs are tactical to investigate the interactions of the volatile chemicals with the surrounding environments as well as to determine and study the emission sources. Table 1 reports some of the most common VOCs and their typical emission sources.

Table 1. Common VOCs and associated emission sources.

\begin{tabular}{ll}
\hline VOC & Typical Emission Sources \\
\hline Propane & Gas grills; gas heaters \\
Butane & Gas grills; gas heaters; gas torches; end-life fridges, and freezers \\
Methyl chloride & Solvents; fire extinguishers \\
Formaldehyde & Plastic furniture items; fiberboards \\
Toluene & Paints; solvents \\
Acetone & Solvents; wallpaper and furniture polish \\
Isopropyl alcohol & Solvents; disinfecting solutions \\
Carbon Tetrachloride & Fire extinguishers; cleaning products \\
Carbon disulphide & Volcanic eruptions; marshes \\
Vinyl chloride & PVC pipes, wire, cable coatings, and textiles; burnt tobacco \\
Benzene & Fuels \\
Styrene & Polystyrene objects, rigid panels, and furnishings \\
Acetic acid & Cellulosic materials such as wood and paper \\
Isoprenoids & Plants \\
\hline
\end{tabular}

Classic methods for the analysis of VOCs are gas and liquid chromatography (GC, LC, HPCL, etc.), whether coupled with other techniques such as mass spectroscopy (MS), time of flight (TOF), thermal desorption (TD), or olfactometric detection (e.g., GC-O), etc. [46-48]. Other techniques include, for example, selected-ion flow-tube mass spectrometry (SIFT- 
MS) or proton-transfer-reaction mass spectrometry (PTR-MS) [49,50]. The analysis of VOCs may be carried out directly injecting the air to be analyzed into the instrument (e.g., headspace analysis) or by firstly adsorbing VOCs on passive or active samplers thus desorbing them in the selected mobile phase for analysis (such as in the case of ion chromatography). These techniques are certainly highly sensitive and efficient but are expensive and energy/time-consuming. In most of the cases they are also not portable, with important drawbacks [51], while the few commercially available portable tools for VOCs analysis are poorly efficient, have high LOD and are not selective to specific VOCs, such as in the case of a photoionization detector (PID) [52].

In the past decades the literature has reported novel VOC sensors and biosensors designed for solving these issues with remarkable results, as reported in different reviews and research papers [53-57]. In general, VOC sensors are devices capable of registering electrical, photophysical, mechanical, or biological changes, after the interaction with specific volatile compounds. These changes are converted into signals, of which the intensity normally depends on analyte concentrations, or analyte chemical and physical characteristics [58]. Among all sensors, the subclass of biosensors indicates sensors containing a biological recognition element, whether that be enzymes, proteins, antibodies, nucleic acids, cells, tissues or receptors, that interact with the VOCs [59-62].

VOC sensors and biosensors have emerged as alternatives to classic analytical tools mainly due to their faster response, cheaper analysis, and portable characteristics, while other features include enhanced selectivity, lower power consumption, or more rapid recovery times. VOC sensors and biosensors have been successfully employed in a large number of applications in food safety analysis, environmental monitoring, clinical analysis and medical diagnosis [63-66]; however, it must be highlighted that the majority of sensors and biosensors reported in previous years were developed without, or by poorly considering any green and sustainable characteristics of the final devices or of the production processes.

Recently, and more specifically in the last couple of years, different national and international policies have started firmly pushing for a sustainable development and a green transition [67-73]. For example, the European Green Deal aims at "making Europe climate neutral by 2050, by boosting the economy through green technology, by creating sustainable industry and transport, and by cutting pollution" [74]. All these policies directly influences any sort of R\&D and R\&I activity [75-78], including the design of novel VOC sensors and biosensors [79].

From this perspective, a review on the most innovative VOC sensors and biosensors recently developed with environmentally friendly and sustainable characteristics is herein reported, integrating the current reviews present in the literature in the field of VOC sensors and biosensors [80-87]. The review highlights recent trends in the research of green approaches to substitute and replace classic poorly sustainable sensors, in line and accordance with the most recent environmental policies and researchers' ethical spirt of sustainable growth. These approaches include manufacturing processes carried out using biomass and waste derived materials, the use of abundant elements in place of rare metals, the design of low energy consuming methods or the exploitation of biological activities, exploiting innovative technologies such as printed electronics, nanotechnology, silicon photonics, or biotechnology [88-90].

The sensors and biosensors herein reported include tools for the direct analysis of air, as well as systems for the detection of VOCs adsorbed and redispersed-using the already cited passive or active samplers-in aqueous solutions (such as electrochemical devices).

The article is presented in a logical form to be informative and pedagogic for anyone looking for a deeper understanding of the topic. The review is divided into three different sections presenting VOC sensors and biosensors in the function of highly captivating applications, including environmental analysis, intelligent food packaging design, and medical diagnosis, making the manuscript attractive for both readers having expertise in the field but also for anyone with no specific knowledge who wants to explore the matter. 
In detail, Section 1 includes sensors and biosensors for environmental analysis, especially focusing on VOCs found in common indoor environments. Section 2 describes VOC sensors and biosensors for food packaging applications, where the detection of VOCs is crucial to understanding the freshness of food and the presence of possible active degradation processes. Section 3 is focused on sensors and biosensors for medical uses, of which the applicability can lead to diagnosing diseases easily and quickly. Each Section firstly discusses the most important VOCs found in the specific field and related challenges, thus, the most recent works on the preparation of sensors and biosensors with green characteristics are reported. The conclusion describes perspectives and challenges for future developments. Figure 2 summarizes the sensors and biosensors for specific VOCs' detection described in each section.

\section{NOVEL SUSTAINABLE VOCs SENSORS AND BIOSENSORS}

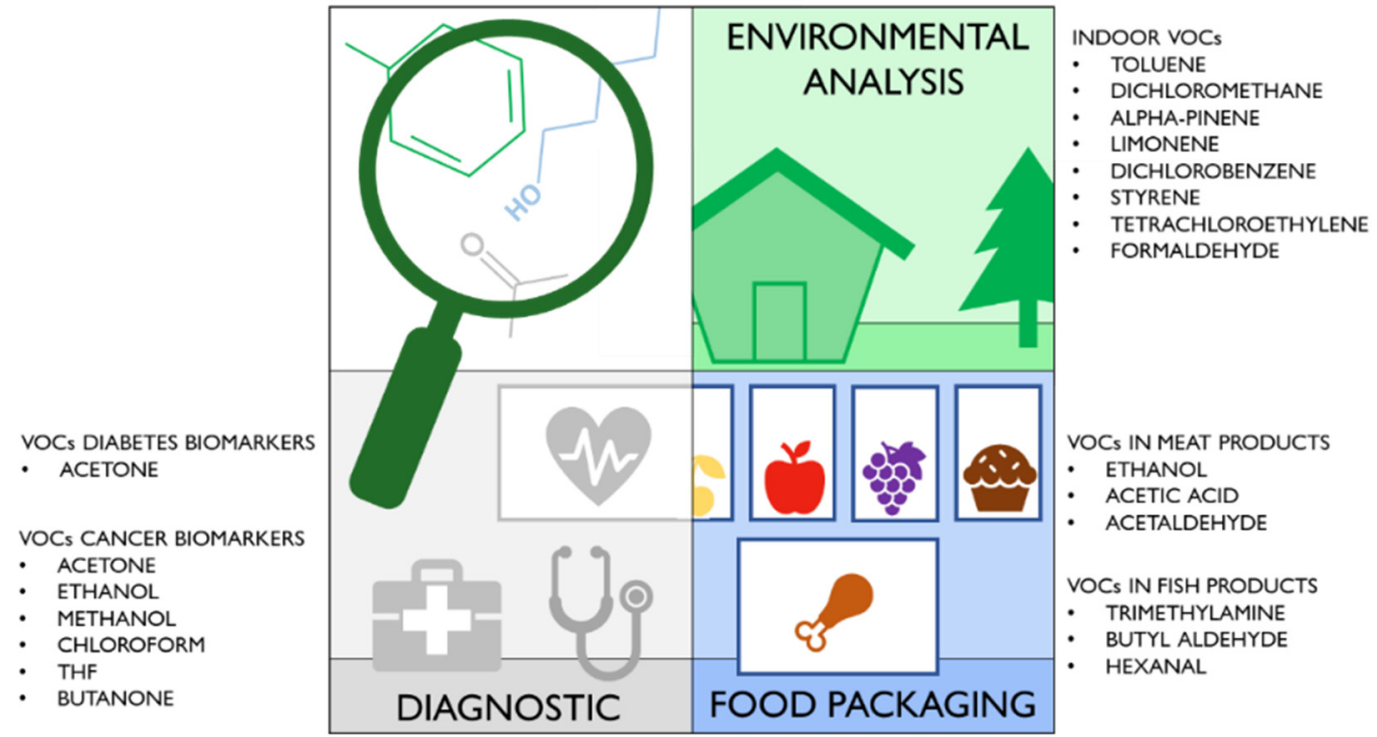

Figure 2. Field of applications of the novel sustainable sensors and biosensors and most relevant analyte VOCs reported in the present review.

\section{Section A: Environmental Analysis}

The environmental analysis of VOCs aims at the detection and quantification of organic compounds that might involve any biological interaction, including human health issues, plant defense mechanisms, animal toxicity concerns, etc. Without considering particular environments or situations, such as the analysis of gas leaching in pipes or in reactors (which can be undertaken, due to extremely high concentrations of VOCs, using low sensitive sensors and tools), the environmental analysis of VOCs is generally related to the selective detection of common indoor pollutants at low concentrations. Many VOCs are indeed classified as toxic and might cause asthma and other respiratory symptoms/diseases, headaches, nausea, or more severe problems such as convulsions and comas [91]. Some VOCs are also recognized as carcinogenic, especially targeting the liver, kidneys, brain, and nervous system [92]. Therefore, the analysis of VOCs in indoor environments is crucial to determine eventual chronic exposition to toxic chemicals and to avoid severe health issues. In this view, the development of sustainable sensors and biosensors for indoor pollutants has gained much interest especially addressing the current directives of sustainable R\&D.

It has been calculated that normally a person spends almost $80 \%$ of its life in indoor environments. Thus, a special focus of environmental analysis is the determination and quantification of VOCs in spaces generally occupied during a day such as homes, offices, schools, classrooms, vehicles, and stores [93,94]. VOCs found in these environments are mainly emitted from sources such as construction materials, furnishing, paints, glues, heating appliances, tobacco smoke, cooking, and cleaning products $[95,96]$. Due 
to the impossibility of tabulating general concentration values in indoor environments, Table 2 reports the most diffused VOCs in houses and in a primary school and their maximum concentrations.

Table 2. Some of the most abundant VOCs normally found in indoor environments such as houses and schools.

\begin{tabular}{|c|c|c|c|}
\hline \multirow[b]{2}{*}{ VOCs } & \multicolumn{3}{|c|}{ Maximum Concentration $\left(\mu \mathrm{g} \mathrm{m}^{-3}\right)$} \\
\hline & $\begin{array}{l}\text { Houses According to } \\
\text { Héroux et al. [97] * }\end{array}$ & $\begin{array}{l}\text { Houses According to } \\
\text { Yamazaki et al. [10] ** }\end{array}$ & Primary School [11] \\
\hline Toluene & 436 & 530 & 117 \\
\hline Dichloromethane & 1687 & / & / \\
\hline$\alpha$-pinene & 801 & / & 506 \\
\hline Limonene & 329 & / & / \\
\hline Dichlorobenzene & 287 & 4900 & / \\
\hline Tetrachloroethylene & 179 & / & / \\
\hline Styrene & 14 & 2000 & 369 \\
\hline Formaldehyde & / & 100 & / \\
\hline Acetaldehyde & / & 150 & / \\
\hline Cumene & 46 & / & / \\
\hline Ethylbenzene & 20 & 590 & 196 \\
\hline Hexane & 39 & / & / \\
\hline Naphthalene & 23 & / & / \\
\hline n-decane & 203 & / & / \\
\hline Xylene & 77 & 310 & 153 \\
\hline
\end{tabular}

Among all VOCs present in these types of environments, researchers' efforts of recent years have specifically focused on the development of greener and more sustainable sensors and biosensors especially aimed at the detection of toluene, dichloromethane, limonene, dichlorobenzene, styrene, tetrachloroethylene, and formaldehyde.

\subsection{Detection of Toluene}

Toluene $\left(\mathrm{C}_{7} \mathrm{H}_{8}\right)$ is an aromatic compound used in the manufacturing of many goods such as foams for furniture and insulation materials, coatings, or shoes. It has a time weighted average (TWA) of $20 \mathrm{ppm}(8 \mathrm{~h})$ and its vapor might irritate the skin, eyes, and the mucous membranes of the throat, possibly causing headache, vertigo, or fatigue [98].

Wang et al. [99] prepared an inexpensive sensor for the detection of toluene based on $\mathrm{Fe}$, one of the most abundant elements in the Earth's crust, and $\mathrm{Ni}$, a metal having important recyclability properties $[75,100]$. The sensor, in the form of mesoporous $\mathrm{NiFe}_{2} \mathrm{O}_{4}$, was synthesized through a solvent-free simple method producing limited quantities of waste. The sensor had a framework thickness ranging from 8.5 to $5 \mathrm{~nm}$ and a specific surface area ranging from 134 to $216 \mathrm{~m}^{2} \mathrm{~g}^{-1}$. During the testing for gas detection, it was proved that the mesoporous $\mathrm{NiFe}_{2} \mathrm{O}_{4}$ with both an ultrathin framework and large specific surface area could detect toluene in concentrations ranging up to $1000 \mathrm{ppb}$, showing that the response, selectivity, and stability were remarkably enhanced with respect to commonly employed NiFe-based sensors.

In previous years, different lanthanide complexes have been reported as simple, sensitive, and inexpensive analytical tools for the determination of many organic solvents, metal ions and in general gases due to their structural and unique luminescent properties. Very recently, they have been also proved to be usable as sustainable sensors for the specific detection of toluene [101]. In details a new sequence of lanthanide metal-organic frameworks (LnMOFs) was prepared though a simple and inexpensive solvothermal reaction, using lanthanide (III) nitrates, methylmalonic acid as the ligand and 1,10-phenanthroline as the capping agent. The luminescence analysis of LnMOFs in the presence of different organic solvents, showed an evident and marked response though the detection of toluene, proving the possible use of LnMOFs as a highly selective luminous sensor for this type of VOC.

Some environmentally friendly carbon dots have been also proposed as possible sensors for organic compounds' detection. For example, Dong et al. recently reported 
the preparation of nitrogen and sulfur doped carbon dots as sensors for toluene [102]. Importantly, the materials were prepared using citric acid as the carbon source, sensibly improving the sustainability of the synthetic process, considering that citric acid might be produced by yeasts via biomass valorization [103].

A few years ago, the possibility was proved of preparing a fiber optic enzymatic biosensor featuring cost-effective, real time, continuous, and in situ measurements of toluene. A sensor was prepared using toluene ortho-monooxygenase (TOM) as the biological recognition element, and an optical fiber coated with an oxygen-sensitive ruthenium phosphorescent dye as the transducer [104]. The detection of toluene was carried out based on the enzymatic reaction catalyzed by TOM, which resulted in the consumption of oxygen and, consequently, changes in the phosphorescence intensity.

\subsection{Detection of Dichloromethane}

Dichloromethane (DCM) $\left(\mathrm{CH}_{2} \mathrm{Cl}_{2}\right)$ is largely used in industry due to its high volatility and ability to dissolve many chemicals and it is used to produce paint removers or adhesives, among others. DCM has a TWA $(8 \mathrm{~h})$ of $50 \mathrm{ppm}$, and its hazardous properties include the irritation of skin and mucous membranes and the cause of headache, vertigo, nausea, vomiting and anemia. It has been classified as likely to be carcinogenic [98].

In the last decade, the quartz crystal microbalance (QCM) technique combined with a surface plasmon resonance (SPR) system using Langmuir-Blodgett (LB) thin films have emerged for the detection of VOCs due to the high sensitivity and reliability of the methodology combined with low experimental costs and limited environmental impact. Durmaz et al. exploited these features to prepare a sensitive LB film coated QCM sensor for the detection of DCM [105]. In detail, a calix[4]arene-dithiourea receptor, denoted "C[4]-DT", was used to form a thin film over quartz crystals for QCM measurements. As shown in Figure 3, the so-prepared C[4]-DT LB film-coated QCM sensor was used for the detection of several VOCs.

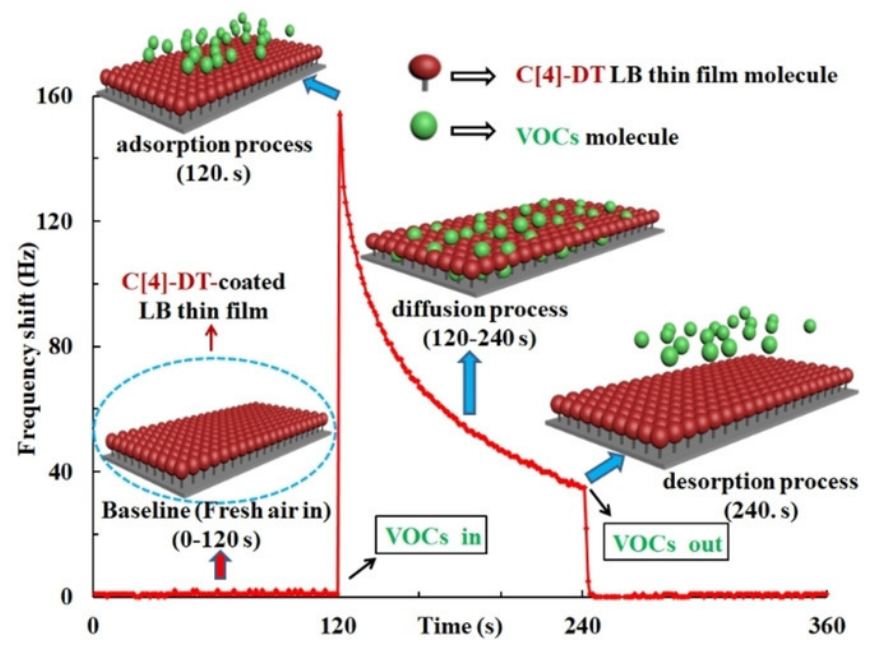

Figure 3. Schematic representation of the interaction of VOCs with the calix[4]arene-dithiourea receptor. Reprinted with permission from ref. [105]. Copyright 2021 Wiley.

The system showed a specifically selective response to the DCM rather than other vapors with a limit of quantification of $0.5 \mathrm{ppm}$. Additionally, the sensor was proved to have a good reproducibility, rapid response time, and excellent full recovery.

Based on the fact that electrochemical methods for the detection of toxic chemicals are particularly highly sensitive, economic, and portable, Shink et al. proposed an environmentally friendly electrode for the detection of DCM based on a zinc oxide modified disposable screen printed electrode (SPE) [106]. In detail, the authors developed a synthetic methodology to produce hexagonal zinc oxide ( $\mathrm{ZnO}$ ) nanopyramids (NPys), of which the morphology could remarkably improve the performance of the sensor. ZnO NPys 
were synthesized by a simple and fast hydrothermal procedure using zinc acetate as the precursor and oleylamine as the surfactant. As illustrated in Figure 4, the sensor showed good behavior in the detection of DMC through a series of cyclovoltammetric (CV) analysis.
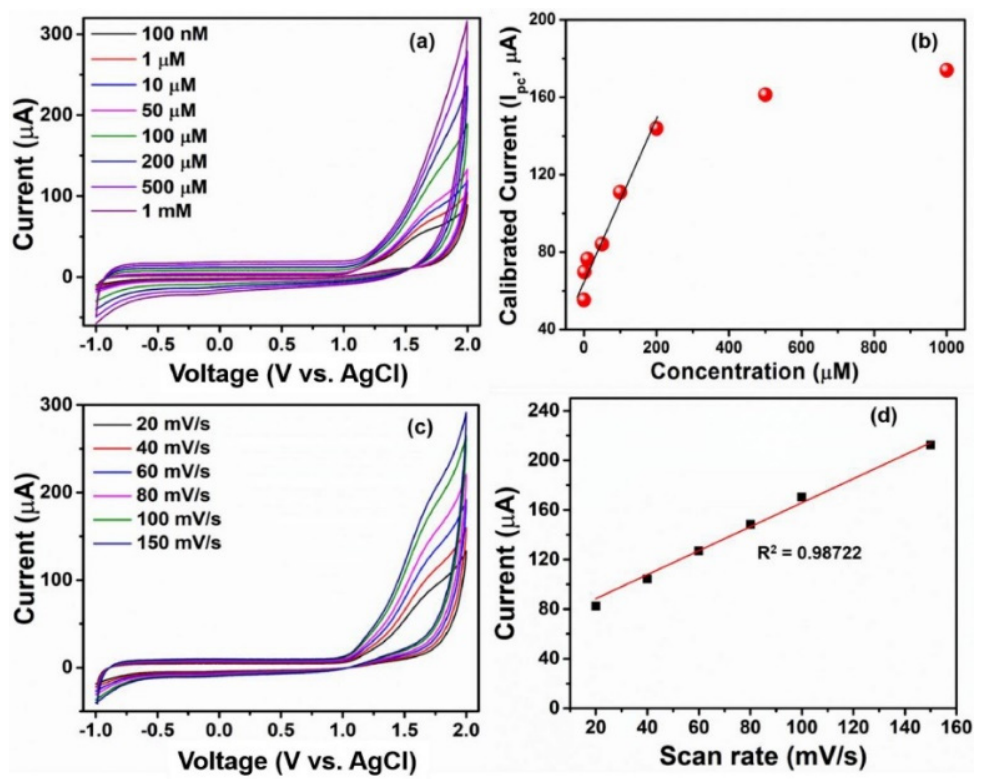

Figure 4. (a) CV curves obtained varying the DCM concentrations from $100 \mathrm{nM}$ to $1 \mathrm{mM}$, (b) calibrated current of cathodic peak versus concentration of DCM chemical, (c) CV measurements at various scan rates and (d) calibrated current at cathodic peak versus scan rate of the hexagonal ZnO NPys modified electrode. Reprinted with permission from ref. [106]. Copyright 2019 Elsevier.

The modified disposable SPE chemical sensor showed a good sensing behavior for the detection of DCM with high sensitivity, a limit of detection of $17.3 \mu \mathrm{M}$ and an excellent linearity in the range of $\sim 100 \mathrm{nM}$ to $200 \mu \mathrm{M}$.

More recently, another study reported the preparation of a highly sensitive sensor for the detection of DCM based on upconverting nanoparticles (UCNPs) [107]. UCNPs are nanoparticles capable of converting low energy incident photons into emitted photons with higher energy, and have particularly emerged for background-free imaging, biological detection, temperature sensing, and many other applications. The key feature of UCNPs is the possibility of preparing sensors with a high sensitivity and a low detection limit along with the important advantage of low energy consumption. The sensor for the detection of DCM was specifically prepared in the form of $\mathrm{NaGdF}_{4}: \mathrm{Yb}, \mathrm{Er} @ \mathrm{NaYF}_{4}: \mathrm{Yb}_{\mathrm{b}}$ active core@shell upconverting nanoparticles (UCNPs) by depositing UCNPs on porous anodic alumina oxide templates supported by glass slides, forming a thin film-like gas sensor. The nanoporous fluorescent sensor was capable of detecting dichloromethane with a detection limit of $2.9 \mathrm{ppm}$ at room temperature.

Different DCM bacteria destructors have also been proved to be suitable for the preparation of sustainable sensors for DCM detection. In detail, ethylobacteria-Methylobacterium dichloromethanicum DM4, Methylobacterium extorquens DM17, Methylopila helvetica DM6, and Ancylobacter dichloromethanicus DM16 immobilized on membranes fixed on a $\mathrm{pH}$-sensitive transistor, could interact with DCM leading to a change in the output signal of the transistor [108].

\subsection{Detection of Limonene and $\alpha$-Pinene}

$\alpha$-pinene $\left(\mathrm{C}_{10} \mathrm{H}_{16}\right)$ and limonene $\left(\mathrm{C}_{10} \mathrm{H}_{16}\right)$ are natural substances mainly found in the oils of coniferous trees ( $\alpha$-pinene) and citrus fruit peels (limonene). $\alpha$-pinene is principally used to produce perfumes and fragrances and has a TWA $(8 \mathrm{~h})$ of 20 ppm. At low concentrations it has therapeutics properties [109], while at high concentration it may cause allergic reactions, and could be highly toxic. 
Limonene has a TWA of $30 \mathrm{ppm}$ and its quite safe for human uses although it may cause allergic reactions and toxicity issues by inhalation at high concentrations. Limonene is used as solvent, fragrance, and insecticide [98].

In a similar manner to the detection of DCM, quartz crystal microbalance (QCM) techniques were also exploited for the detection of limonene and $\alpha$-pinene. In detail, a sensor for the detection of limonene was prepared using a QCM chip as the sensor transducer and ethyl cellulose as the sensing material [110]. The use of ethyl cellulose (EC) is of particular interest since EC is derived from cellulose, i.e., the most renewable natural polymer on Earth [111]. The sensor was specifically proved to detect limonene up to $6000 \mathrm{mg} \mathrm{m}^{-3}$, with a limit of detection (LOD) of $300 \mathrm{mg} \mathrm{m}^{-3}$. The sensor was also demonstrated to be stable and efficient since it could be used for up to five cycles and for a month before observing significant losses of activity.

On the other hand, the detection of $\alpha$-pinene is quite complicated and few works have reported the successful design of novel sustainable sensors, making the research highly challenging. Among the few outstanding examples, a sensor for the detection of $\alpha$-pinene was prepared by manufacturing a highly selective molecularly imprinted polymer (MIP) layer combined with an interdigitated electrode (IDE) as a sensor. Importantly, the IED was prepared using methacrylic acid (MAA) as the sensing material [112]. The sensor was proved to be remarkably selective and efficient. Significantly, considering that it has been recently demonstrated that it is possible to produce MAA from biomass-derived glucose, the manufacturing of this sensor can be considered potentially sustainable, as summarized in Figure 5 [113].

(a)

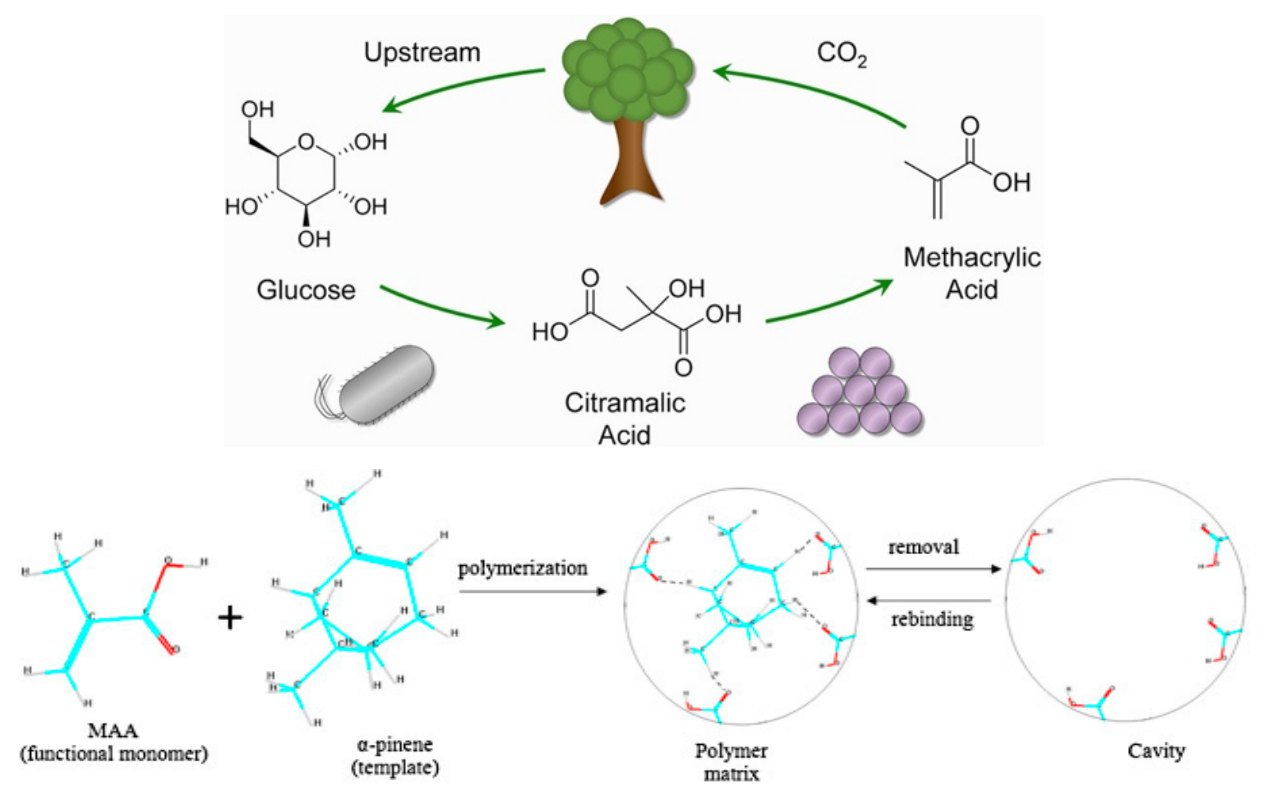

Figure 5. (a) Scheme of the hybrid fermentation and thermocatalysis to produce methacrylic acid (MAA) from glucose. Reprinted with permission from ref. [113]. Copyright 2021 American Chemical Society. (b) Illustration of molecular imprint polymer (MIP) concept made of MAA. Reprinted with permission from ref. [112]. Copyright 2013 Elsevier.

\subsection{Detection of Dichlorobenzene}

Dichlorobenzene (DCB) $\left(\mathrm{C}_{6} \mathrm{H}_{4} \mathrm{Cl}_{2}\right)$ in its three different isomeric forms $(1,2 ; 1,4$ and $1,3)$ is used in space deodorants, fumigants, insecticides, and herbicides as well as in the synthesis of dyes and resins. The lower value of TWA $(8 \mathrm{~h})$ of DCB (corresponding to 1,4-dichlorobenzene) is $25 \mathrm{ppm}$. Inhalation of the vapor of DCB results in irritation to the eyes, skin, and throat. DCB has also the potential to cause cancer [98].

A few years ago, Chao et al. demonstrated the possibility of producing mesoporous molecular sieves MCM-41 from coal fly ash at room temperature via a green and efficient 
reaction [114]. MCM-41 is a widely used material with applications in catalysis, separation processes, and adsorption of gases and liquid. This last feature was specifically exploited by Rahman et al. to design a simple, inexpensive, potentially sustainable, consistent, portable, and reliable chemical sensor for 1,2-dichlorobenzene detection [115]. The sensor was fabricated by depositing a thin layer of MCM-41 on a glassy carbon electrode (GCE). The sensor, used through an electrochemical approach, showed good sensitivity and a short response time of $14.0 \mathrm{~s}$, while the linear dynamic range and the detection limit were reported as $0.089 \mathrm{nM}$ to $8.9 \mathrm{mM}$ and $13.0 \mathrm{pM}$, respectively.

\subsection{Detection of Styrene}

Styrene $\left(\mathrm{C}_{8} \mathrm{H}_{8}\right)$ is extensively used in the manufacturing of numerous polymers and copolymers such as polystyrene, acrylonitrile-butadiene-styrene (ABS), styrene-butadiene latex, for the fabrication of different goods including foam packaging, toys, shoes, and furnishings. Styrene has a TWA $(8 \mathrm{~h})$ of $20 \mathrm{ppm}$, and its vapor irritates the eyes and mucous membranes. The inhalation of high concentrations of styrene can cause polyneuritis. It is also reasonably anticipated to be a human carcinogen [98].

Recently, Bi et al. developed a Terbium-based metal-organic frameworks (MOF) for the efficient detection of styrene. Td-MOF $\left(\mathrm{Tb}^{3+}\right)$ was prepared based on an innovative, facile, and low-energy consuming (at room temperature) method [116]. Td-MOF was thus homogeneously embedded into a PVA film and deposited on silica gel sheets, forming a luminescent vapor sensor film for styrene detection. A sequence of photoluminescence (PL) tests demonstrated that $\mathrm{Tb}-\mathrm{MOF}$ showed a significant response rate and high sensitivity to styrene vapor. In addition, as shown in Figure 6a, time-dependent fluorescence quenching indicated that the emission of the film was immediately quenched by exposure to styrene vapor (in only $30 \mathrm{~s}$ ), and the intensity remained unchanged over time, proving an excellent sensitivity performance. Recyclable tests, i.e., by carrying out experiments followed by a drying procedure in an oven, also proved the good reversibility and reusability of the Td-MOF, as illustrated in Figure 6b.
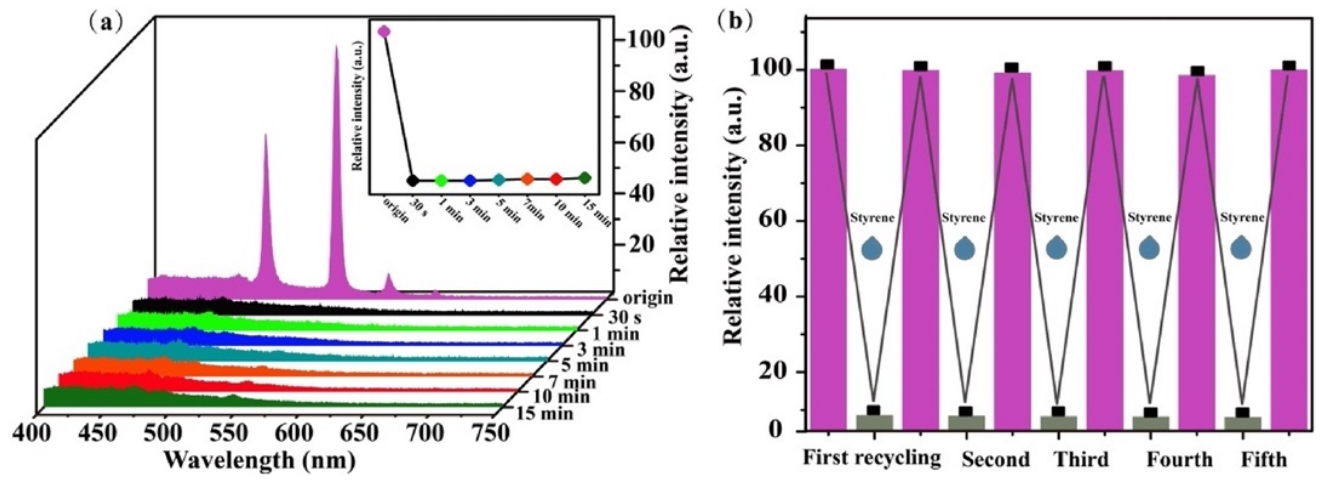

Figure 6. (a) Time-dependent emission spectra of the Tb-MOFs film responded to $20 \mu \mathrm{L}$ styrene vapor; (b) Emission intensity of five recyclable experiments of sensing styrene, Reprinted with permission from ref. [116]. Copyright 2020 Elsevier.

A few years ago the possible utilization of bacteria for the preparation of biosensors for styrene detection was also demonstrated, such as in the case of a biosensor based on the regulation system of the styrene catabolic pathway present in the Pseudomonas sp. strain Y2 [117]; however, this type of approach has not been followed up in recent years, although it has tremendous potentialities.

\subsection{Detection of Tetrachloroethylene}

Tetrachloroethylene $\left(\mathrm{C}_{2} \mathrm{Cl}_{4}\right)$ is principally used as a chemical intermediate and as a solvent in the textile and metal industries. Tetrachloroethylene has a TWA $(8 \mathrm{~h})$ of $25 \mathrm{ppm}$ and the exposure to its vapors can cause eye irritation, narcotic action, vertigo, nausea, and headache. Tetrachloroethylene is also suspected to cause cancer [98]. 
A $\mathrm{ZnO}$-based sensor capable of detecting tetrachloroethylene was recently proposed by Zhao et al. [118]. In detail, the researchers developed a new method for the chip-level pyrolysis of as-grown zeolitic imidazolate framework films to hierarchical and structured $\mathrm{ZnO}$ sheets composed of interpenetrated nanometer particles. The tunable introduction of interpenetrated particles generated adjustable oxygen vacancies, modifying the electronic structure of the sensing materials. As a result, the sensors showed improved diffusion, penetration, and adsorption of the relevant gases, resulting in enhanced sensitivity and a shortened response time toward the detection of different VOCs at the ppb-level, including tetrachloroethylene. The facile synthetic approach using a largely available material, i.e., $\mathrm{ZnO}$, made the novel sensor a good candidate for sustainable scaled-up productions and commercialization.

\subsection{Detection of Formaldehyde}

Formaldehyde $\left(\mathrm{CH}_{2} \mathrm{O}\right)$ is used in the manufacturing of many different products including adhesives, abrasive materials, insulating materials, coatings, and polyacetal plastics-based materials. In indoor environments it is mostly emitted from building materials. Formaldehyde is a highly toxic chemical with a TWA $(8 \mathrm{~h})$ of $0.1 \mathrm{ppm}$. The inhalation of formaldehyde irritates the mucous membranes, while chronic symptoms include renal and hepatic damage. It is considered cancerogenic [98].

Recently, Lee et al. reported the manufacturing of a monolithic flexible sensor for the detection of formaldehyde at the ppb-level [119]. The sensor was produced by depositing a $\mathrm{TiO}_{2}$ sensing film on a polyethylene terephthalate substrate and by covering the film with an overlayer of molecular sieving a ZIF-7/polyether block amide (mixed matrix membrane, MMM). The sensor was designed to selectively detect formaldehyde by a sensing photoactivation at room temperature. The sensor showed ultrahigh selectivity (response ratio $>50$ ) and response (resistance ratio $>1100$ ) to the exposure at only 5 ppm of formaldehyde. Figure 7 illustrates the selectivity toward the detection of formaldehyde of the novel $\mathrm{MMM} / \mathrm{TiO}_{2}$ sensor also in the presence of ethanol (normally sensibly affecting the detection of formaldehyde).

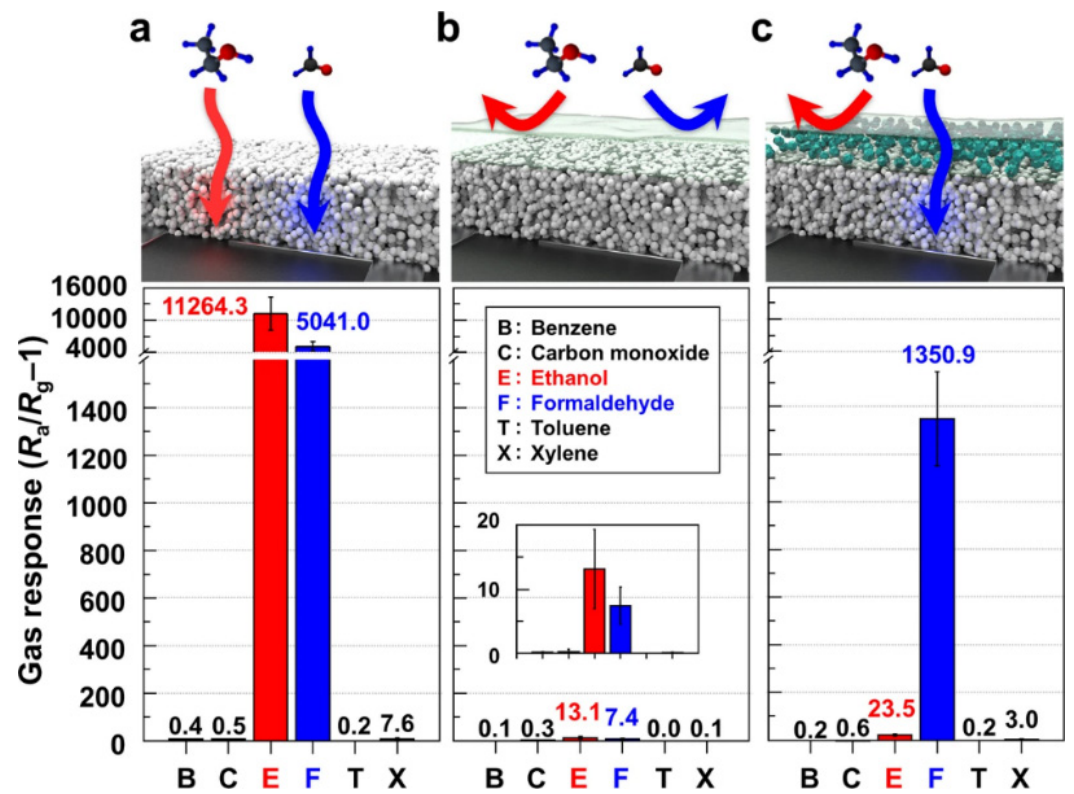

Figure 7. (a) Gas responses of a bare $\mathrm{TiO}_{2}$, (b) Pure $\mathrm{PEBA} / \mathrm{TiO}_{2}$, and (c) $5 \mathrm{MMM} / \mathrm{TiO}_{2}$ sensors exposed to $5 \mathrm{ppm}$ benzene, carbon dioxide, ethanol, formaldehyde, toluene, and p-xylene at $23^{\circ} \mathrm{C}$ under UV illumination $(\lambda: 365 \mathrm{~nm})$. Error bars represent SD of the mean. Reprinted with permission from ref. [119]. Copyright 2021 Springer Nature. 
A high-performance formaldehyde sensor was prepared by a surface micro-fabrication technique depositing a $\mathrm{LaFeO}_{3}$ (LFO) thin film on a silica substrate [120]. The sensing performances demonstrated that the novel formaldehyde sensors had a remarkable sensitive response and low detection limit toward the ppb-level. In detail, the sensor exhibited a detection limit of $50 \mathrm{ppb}$ and outstanding replicability with a maximum drift of the baseline resistance from different batches of the sensor gas sensors of only $5.4 \%$, and the maximum drift of the response value of $6.5 \%$. In addition, the response values of the sensors remained stable for up to 18 days, with an absolute deviation of response value of approximatively 0.04 .

Other recent sustainable approaches for the preparation of sensors for formaldehyde detection include the use of largely available and inexpensive materials such as tin and zinc [121-128], the second most abundant element in the Earth's crusts, i.e., silicon [129,130], the use of biomass-derived materials, such as bacterial cellulose [131] or egg-white [132].

A biosensor based on formaldehyde dehydrogenase and chitosan has also been recently reported [133]. The sensor was prepared through a low-cost inkjet printing technology by depositing a polyion-complex of FDH and chitosan on an electrode connected with an organic field-effect transistor. The biosensor could detect formaldehyde with an LOD of $3.1 \mu \mathrm{M}$ in aqueous solution.

\section{Section B: Food Packaging}

The demands of the users (food producers, food processors, logistic operators, distributors, and consumers) in the food industry sector are increasing in terms of food safety, quality, and traceability [134]. Throughout the food chain (production, storage, transport, and sale) there are a wide variety of factors (microorganisms, enzymes, temperature, etc.), that can corrupt food products and reduce their shelf life. This is the reason why, in particular, food packaging plays a key role in maintaining the quality of food as well as preserving it from contamination [135]. Traditional packaging systems merely isolate food from the external environment without providing information on the freshness or condition of the food beyond the expiration date. Thus, it is constantly necessary to innovate in the field of food packaging, not only to reduce its environmental footprint, but also to increase its functions. In this scenario arises intelligent packaging, a new packaging technology that integrates traditional packaging systems with intelligent functionalities, including the monitoring of changes in the food product, as well as quality and safety information [136,137], by temperature, humidity, $\mathrm{pH}$, and light exposure measurements [138-141], or through the detection of specific VOCs [134,142-145]. For example, 1-butanol $\left(\mathrm{C}_{4} \mathrm{H}_{10} \mathrm{O}\right)$, 1-hexanol $\left(\mathrm{C}_{6} \mathrm{H}_{14} \mathrm{O}\right)$, 2-ethyl-hexanol $\left(\mathrm{C}_{8} \mathrm{H}_{18} \mathrm{O}\right)$, 1-octen-3-ol $\left(\mathrm{C}_{8} \mathrm{H}_{16} \mathrm{O}\right)$, butanal $\left(\mathrm{C}_{4} \mathrm{H}_{8} \mathrm{O}\right)$, hexanal $\left(\mathrm{C}_{6} \mathrm{H}_{12} \mathrm{O}\right)$ and nonanal $\left(\mathrm{C}_{9} \mathrm{H}_{18} \mathrm{O}\right)$, which are indicators of freshness in food products, while other VOCs, such as fatty volatile acids, are produced during the spoilage of foods [146].

When it comes to incorporating sensing technologies into food packaging materials, the industry trend is to do so for meat or fish products [147].

\subsection{VOCs Detection in Meat Products}

Microbial growth, oxidation and enzymatic autolysis are the three main mechanisms of meat deterioration. During meat spoilage, proteins and lipids decompose to form new compounds that negatively affect product quality. The intrinsic factors related to meat spoilage include $\mathrm{pH}$, water activity and nutrient content of the meat, while extrinsic factors include temperature and atmospheric conditions surrounding the product [148]. For example, when microbial spoilage occurs, there is a decrease in $\mathrm{pH}$ due to the release of lactic acid. The microbes commonly associated with this phenomenon are of the genus Pseudomonas and a traditional sensor/biosensor should detect specific Pseudomonas presence by antigen/antibody reactions or similar [149]. Since microbial spoilage may not occur homogeneously throughout the meat product and the detection of these bacteria would require the sensor to be in direct contact with the entire product, it is most desirable that the target product detected by the sensor be a gaseous by-product released into the 
packaging space. Under normal packaging conditions, several metabolites are formed in the packaging space including $\mathrm{CO}_{2}, \mathrm{O}_{2}$, volatile nitrogen compounds and biogenic amines. As far as this review is concerned, it should be mentioned that the most common VOCs released during meat spoilage are alcohols, phenols, ketones, acids and sulfur-containing compounds [150].

Regarding the detection of VOCs in the meat industry, the most common trends have been towards the detection of alcohols or acetic acid. This is because alcohols such as 3-methyl-1-butanol $\left(\mathrm{C}_{5} \mathrm{H}_{12} \mathrm{O}\right)$ or 1-hexanol $\left(\mathrm{C}_{6} \mathrm{H}_{14} \mathrm{O}\right)$ are indicative of Salmonella contamination in packaged beef, while acetic acid is an indicator of microbial population growth. Hence, Sankaran et al., elaborated olfactory bio-derived sensors mimicking insect odorant binding protein to detect them in low concentrations at room temperature. These were biosensors based on quartz crystal microbalance (QMC) with synthetic peptides. This peptide sequence acting as the sensing material was derived from the amino acid sequence of the LUSH protein from Drosophila odorant binding protein and can detect alcohols with estimated lower detection limits of $<5$ ppm [151,152]. On the other hand, in order to be able to detect acetic acid even at low concentrations (1-3 ppm), Panigrahi et al., prepared quartz crystal microbalance (QMC) sensors deposited over synthetic polypeptide [153]. Recently, Han developed a new gas sensor employing $\mathrm{ZnO}$ foam as the sensing material aimed at acetic acid with superior sensing performances [154].

The latest advances in the development of sensors for the detection of alcohols in packaged meat concerned the detection of ethanol $\left(\mathrm{C}_{2} \mathrm{H}_{5} \mathrm{OH}\right)$. Senapati and Sahu prepared an $\mathrm{Au}$ patch electrode $\mathrm{Ag}-\mathrm{SnO}_{2} / \mathrm{SiO}_{2} / \mathrm{Si}$ metal-insulator-semiconductor capacitive gas sensor with a high sensitivity $(10 \mathrm{ppm})$ for chicken meat samples [155]. The sensor was prepared using a considerably high amount of inexpensive and largely available Sn and $\mathrm{Si}$, although, it is worth mentioning that the response of these sensors to ethanol is lower than to other gases such as ammonia and trimethylamine or hydrogen sulfide, as shown in Figure 8 .

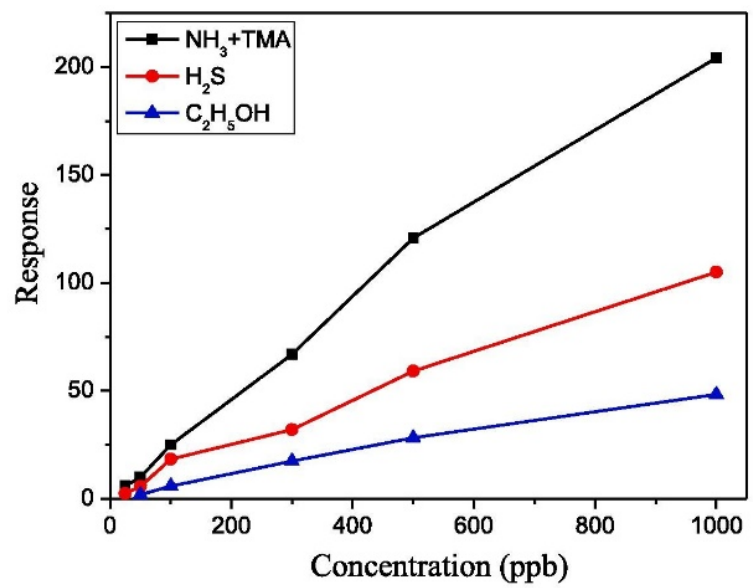

Figure 8. Response curve of $\mathrm{Au}$ patch electrode $\mathrm{Ag}-\mathrm{SnO}_{2} / \mathrm{SiO}_{2} / \mathrm{Si}$ metal-insulator-semiconductor capacitive gas sensor for increasing concentrations of ammonia and trimethylamine $\left(\mathrm{NH}_{3}+\mathrm{TMA}\right)$, hydrogen sulfide $\left(\mathrm{H}_{2} \mathrm{~S}\right)$ and ethanol, Reprinted with permission from ref. [155]. Copyright 2020 Elsevier.

In recent years, the detection of other VOCs related to meat spoilage has also been studied. Acetaldehyde $\left(\mathrm{C}_{2} \mathrm{H}_{4} \mathrm{O}\right)$, resulting from ethanol metabolism, is one of the most important compounds to consider in sophisticated packaging systems. This compound is classified as carcinogenic, and its TWA $(8 \mathrm{~h})$ is $25 \mathrm{ppm}$ [156]. It is therefore important to be able to detect this compound quickly and efficiently. Kim et al. fabricated a surface acoustic wave (SAW) sensor that evaluated the storage time of chicken meat (up to 15 days) as a function of increasing acetaldehyde concentration. These authors verified the feasibility of PDMS polymer composite sensors coated with a layer of the SAW device for the detection of aldehyde gas with a 0.989 coefficient of determination between the gas and storage time 
of chicken meat [157]. Lastly, another VOC released during the spoilage of meat products, and thus acting as a marker, is dimethyl sulfide (DMS, $\mathrm{C}_{2} \mathrm{H}_{6} \mathrm{~S}$ ). For its detection, Chow developed environmentally friendly chemosensors based on bimetallic donor-acceptor ensembles (BmDAE) with a selectivity toward DMS $1.0 \mathrm{ppm}$ in real beef samples. This selectivity was clearly observable to the naked eye, since the chemosensor only turned pink in the presence of DMS (Figure 9a). Moreover, the chemosensor response was correlated with the microbial growth level and the storage time, as shown in Figure 9b [158].

a)

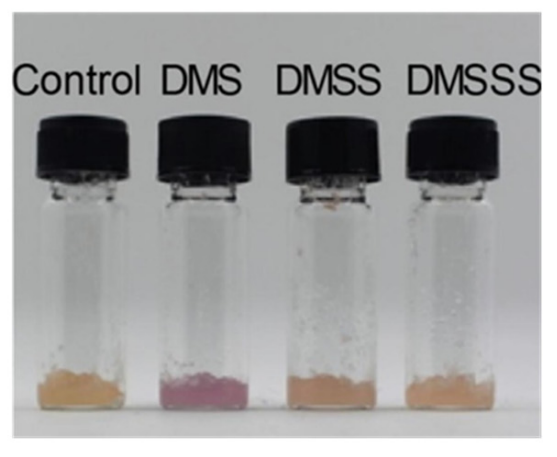

b)

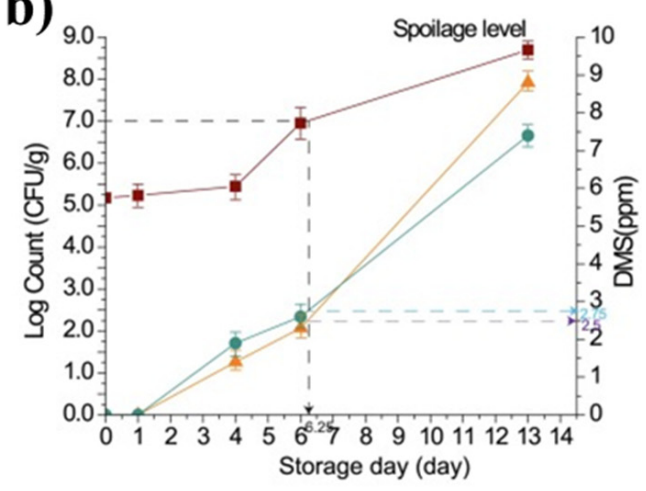

Figure 9. (a) Naked-eye sensing response of solid-supported chemosensor toward DMS; (b) changes in microbial counts (brown line) and DMS concentration measured by UV-Vis (green line) and GC-MS (orange line) for beef samples stored at $4{ }^{\circ} \mathrm{C}$. Reprinted with permission from ref. [158]. Copyright 2019 Elsevier.

\subsection{VOCs Detection in Fish Products}

The consumption of fish or fish-based products is booming due to their health benefits; however, these products are extremely perishable, so it is necessary to develop non-invasive techniques that allow the freshness of the food to be known in more detail rather than just the packaging date. As with meat products, certain VOCs produced by microbial, enzymatic, or autolytic activities during fish spoilage have been identified [159]. Therefore, developing sensors for detecting these compounds is a promising approach.

One of the most characteristic VOCs released during fish spoilage is trimethylamine (TMA, $\mathrm{C}_{3} \mathrm{H}_{9} \mathrm{~N}$ ), a chemical produced through the decomposition of proteins, carbohydrates, and fats. Recently, Perillo and Rodríguez employed $\mathrm{TiO}_{2}$ membrane nanotubes supported on a flexible substrate as a sensor for TMA detection. This sensor was developed using a simple electrochemical anodization and was able to detect TMA at low temperatures in a very wide detection range (40-400 ppm, Figure 10a) [160]. Importantly, $\mathrm{TiO}_{2}$ is a largely available oxide with a very low impact on human health. Other types of sensors that can be used in the detection of TMA in canned fish are those reported by Yang et al. In this case, the authors employed $\alpha-\mathrm{Fe}_{2} \mathrm{O}_{3}$ snowflake-like hierarchical architectures as a TMA gas sensor. The sensors showed an ultra-fast response of 0.9 and $1.5 \mathrm{~s}$ for response time and recovery time, respectively, for TMA and other testing gases such as ethanol, acetone, toluene, methanol and ammonia with a sensitivity of 100 ppm, as illustrated in Figure 10b [161]. Along the same lines, Liu et al., (2020) incorporated $\alpha-\mathrm{Fe}_{2} \mathrm{O}_{3}$ nanoparticles in thick films for the detection of TMA in fish. These sensors showed very good selectivity and high sensitivity for TMA with a minimum detection of 1 ppm, as illustrated in Figure 10c [162]. This same metal oxide has been employed by Shen et al. for the development of $\alpha-\mathrm{Fe}_{2} \mathrm{O}_{3}$ modified Au@Pt bimetallic hollow nanocube sensors. These sensors showed a very fast response time (5 s) towards 100 ppm TMA in Larimichthys crocea [163]. All these approaches followed the idea of exploiting an abundant element, i.e., Fe, of which its sustainable use has been already discussed. 
a)

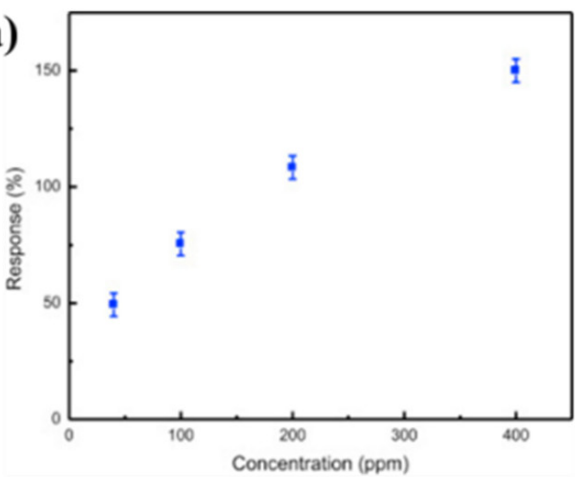

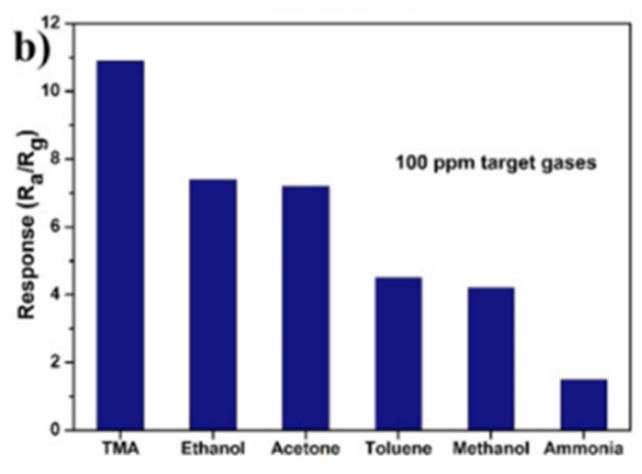

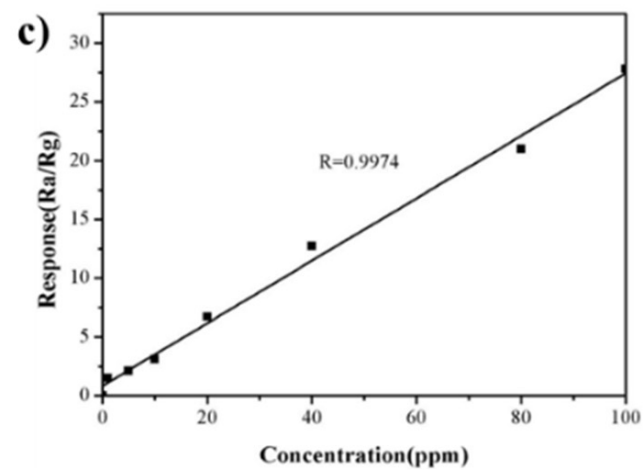

Figure 10. (a) $\mathrm{TiO}_{2}$ nanotubes sensor response to increasing TMA concentrations (40-400 ppm). Reprinted with permission from ref. [160]. Copyright 2016 Elsevier. (b) Response of snowflakelike $\alpha-\mathrm{Fe}_{2} \mathrm{O}_{3}$ hierarchical architectures toward $100 \mathrm{ppm}$ of various testing gases Reprinted with permission from ref. [161]. Copyright 2017 Elsevier. (c) Response of $\alpha-\mathrm{Fe}_{2} \mathrm{O}_{3}$ sensor to increasing concentrations of TMA gas (1-100 ppm) Reprinted with permission from ref. [162]. Copyright 2020 Frontiers Media SA.

TMA detection can be also carried out by colorimetric changes. Lv et al. laid the groundwork for the reaction mechanism of a set of colorimetric sensors that included chromogenic materials sensitive to TMA during the deterioration of packaged fresh mackerel. The authors selected six types of metalloporphyrins and tetraphenyl porphyrins (TPP) and showed that MnTPP, NiTPP and FeTPP had the best binding capacity to TMA. Thus, metal porphyrins can be employed for the construction of colorimetric sensors for TMA [164]. Meanwhile, Sun et al. developed a colorimetric printed freshness indicator for fish in modified atmosphere packaging (MAP) [165]. These authors prepared a printable ink based on a natural purple cabbage pigment-which can be potentially also extracted form waste cabbage [166] — carboxymethyl cellulose and glycerin, screen printed it on paper and applied it to grass carp MAP. This label darkens as the TMA content in the fish sample increases as an indicator of spoilage, as shown in Figure 11. The freshness of fish can also be measured non-destructively using fluorescent films. Lai et al. developed highly emissive amorphous tetraphenylethylene (TPEBA) nanoparticles capable of detecting TMA with a detection limit of $0.89 \mathrm{ppm}$ in butterfish [167]. Finally, the most recent advance in the detection of TMA in fish has been the one proposed by Praoboon et al. [168]. The authors developed a paper-based electrochemiluminescence device for the estimation of TMA concentration in freshwater and marine fish samples (red tilapia, yellow tail, salmon, tuna, and catfish). The key to these sensors lay in the fast response they provided ( $2 \mathrm{~min}$ ) for a TMA concentration range from $1 \times 10^{-12}$ to $1 \times 10^{-6} \mathrm{M}$. 


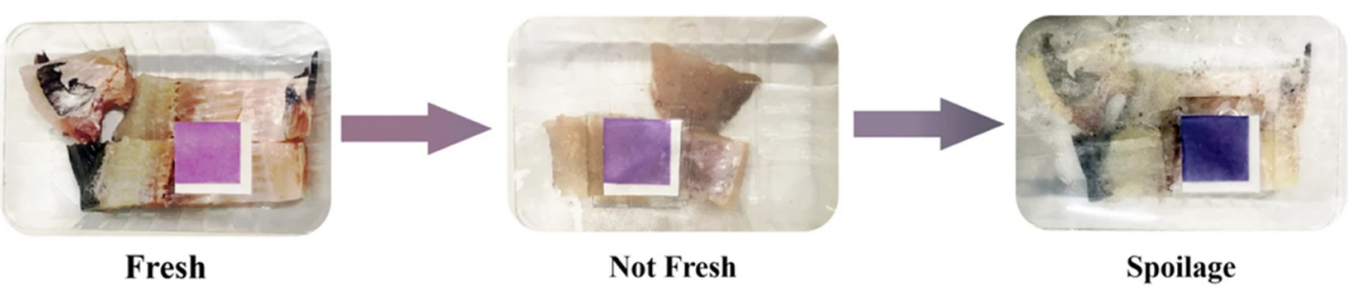

Figure 11. Color change of printable colorimetric paper sensor during monitoring of the freshness of the grass carp within $24 \mathrm{~h}$ at $25^{\circ} \mathrm{C}$ by Sun et al., Reprinted with permission from ref. [165]. Copyright 2021 Springer Nature.

Although to a lesser extent than the TMA, aldehydes such as hexanal $\left(\mathrm{C}_{6} \mathrm{H}_{12} \mathrm{O}\right)$, octanal $\left(\mathrm{C}_{8} \mathrm{H}_{16} \mathrm{O}\right)$ and nonanal $\left(\mathrm{C}_{9} \mathrm{H}_{18} \mathrm{O}\right)$ are also released from fish products such as grass carp or hairtail fish. In this sense, Jia et al. developed a predictive model to determine the freshness of salmon during cold storage. The authors employed electronic nose with principal component analysis (PCA) and radial basis function neural networks (RFBNN). This system allowed the detection of VOCs such as butyl aldehyde $\left(\mathrm{C}_{4} \mathrm{H}_{8} \mathrm{O}\right)$, amyl aldehyde, hexanal, heptanal $\left(\mathrm{C}_{7} \mathrm{H}_{14} \mathrm{O}\right)$, 1-propanol $\left(\mathrm{C}_{3} \mathrm{H}_{8} \mathrm{O}\right)$, and 1,2-butanone amyl alcohol, which increased proportionally with the level of salmon spoilage [169]. Lastly, Chen et al. prepared a quartz crystal microbalance (QMC) gas sensor modified with the hydrophobic aminofunctionalized graphene oxide (AGO) nanocomposite for aldehydes detection in grass carp fish fillets and hairtail fillets. These sensors responded towards aldehydes within $45 \mathrm{ppm}$ under $80 \%$ relative humidity during refrigerated storage at $4{ }^{\circ} \mathrm{C}[170]$.

\section{Section C: Diagnostic}

As estimated by the World Health Organization [171], every year 12 million global deaths (nearly $25 \%$ of total deaths) are attributable to unhealthy environments. Environmental hazards, in particular water, air, and soil pollution, causes hundreds of diseases and health problems. In addition, the WHO has pointed out that two-thirds of the total deaths related to unhealthy environments come from noncommunicable diseases (NCD) such as heart diseases, autoimmune diseases, diabetes, strokes, cancers, and others. The same institution reported that yearly about eight million people die due to the delayed diagnosis of NCD.

An effective strategy to prevent these deaths is the development of devices allowing an early diagnosis of the diseases. The accurate identification and quantification of VOCs emitted from the body can indeed provide information on health and metabolic pathological conditions. In particular, VOC sensors have gained considerable interest for the selective and continuous diagnosis of various physiological and pathological states acting as biomarkers for the identification of numerous diseases in a non-invasive way [172-175]. Indeed, the key factor of this type of analysis is the detection of VOCs in the exhaled breath of patients through simple, efficient, and inexpensive tools [176-178]. For example, some VOCs such as acetone, benzene, ethanol, and isoprene are related to specific diseases and could be used as biomarkers of diabetes, genetic disorders, infectious, cancerous, or renal diseases $[75,179,180]$.

In recent years, scientific efforts have especially focused on the design of environmentally friendly sensors and biosensors for the sustainable diagnosis of cancer and diabetes. Moreover, some remarkable results have been also obtained in the diagnosis of asthma, chronic obstructive pulmonary disease, cystic fibrosis, liver cirrhosis and tuberculosis [181-185].

\subsection{Diabetes Diagnosis}

The traditional method for checking diabetes involves collecting blood samples. This type of analysis is precise and accurate but painful, expensive, and invasive. Alternatively, it has been demonstrated that diabetes can be diagnosticated in a non-invasive way by detecting different gaseous VOCs in breath samples. Indeed, the concentrations of olfactory 
markers of the breath in diabetic patients show significant differences compared to those of healthy patients. For example, acetone $\left(\mathrm{CH}_{3} \mathrm{COCH}_{3}\right)$ is one the most studied and recognizable VOCs for diabetes diagnosis [186], considering that acetone concentration in diabetic patients is higher than $1.8 \mathrm{ppm}[187,188]$.

Ma et al. [189] developed a sensor for acetone detection based on $\mathrm{Ni}$, a metal having important recyclability properties, and $\mathrm{Fe}$, one of the most abundant chemical elements in the Earth's crust. Porous $\mathrm{NiFe}_{2} \mathrm{O}_{4}$ microspheres were synthetized using an easy procedure, combining a solvothermal step with a heating annealing methodology. As proved by experimental tests, the gas sensors showed a high response to $100 \mathrm{ppm}$ acetone, a low detection limit (200 ppb) and excellent reusability.

A high-performant $\mathrm{NiO} / \mathrm{SnO}_{2}$ acetone sensor was also prepared via a facile hydrothermal protocol [190]. The gas sensor exhibited improved performances compared to pure tin oxide and showed a fast response, low detection limit (10 ppb) and good selectivity. Similarly, a $\mathrm{SnO}_{2} / \mathrm{ZnO}$-based sensor able to detect acetone was recently proposed by Dong et al. [191]. In detail, an electrospinning step and a low temperature water bath method was developed for designing $\mathrm{SnO}_{2} / \mathrm{ZnO}$ hetero nanofibers. The sensor was tested with an acetone concentration range of 1 to $100 \mathrm{ppm}$. The results demonstrated that $\mathrm{SnO}_{2} / \mathrm{ZnO}$ materials exhibited fast response values, and a remarkable, high selectivity to acetone.

A few years ago, Zhang et al. reported a one-step route to prepare $\mathrm{C}_{3} \mathrm{~N}_{4}-\mathrm{SnO}_{2}$ nanocomposites with an outstanding acetone sensing performance [192]. $\mathrm{C}_{3} \mathrm{~N}_{4}$ and $\mathrm{SnO}_{2}$ are eco-friendly, economic, and easy-to-prepare materials, and the synthetic procedure reported by the researchers was simple, repeatable, and operable. The sensors exhibited about a 20 times improvement of the response sensitivity as well as remarkable selectivity, fast response and repeatability compared with pure tin oxide. The detection limit of $67 \mathrm{ppb}$ was remarkably below the acetone content of diabetes patients' exhaled breath.

Recently, $\mathrm{ZnFe}_{2} \mathrm{O}_{4}$ has also attracted considerable interest due to its environmentally friendly characteristics, low cost, and excellent stability. Huang et al. designed $\mathrm{ZnFe}_{2} \mathrm{O}_{4}$ nanorods through an easy hydrothermal route [193] with a high gas response of acetone.

Another study reported the microwave-assisted synthesis of a sensor for the detection of an acetone based on a $\mathrm{Co}_{3} \mathrm{O}_{4} / \mathrm{rGO}$ nanocomposite [194]. Microwave (MW) irradiation is recognized as a time-saving heating method with remarkable environmentally friendly characteristics such as minimized heating loss and improved energy efficiency $[75,195,196]$. The tests showed that the materials achieved remarkable response to acetone $(0.5 \sim 200 \mathrm{ppm})$ and good selectivity against the gases of hydrogen, methane, hydrogen sulphide, formaldehyde, methanol, methoxyethane and ethanol.

\subsection{Cancer Diagnosis}

Commonly used methodologies for cancer diagnosis implies bronchoscopy and diagnostic imaging (CT scan). These analyses entail some drawbacks such as weak sensitivity or the use of expensive tools. Moreover, bronchoscopy involves anesthesia, which is sometimes correlated with trauma and complications. In the past decade, the detection of specific VOC biomarkers has been identified as a new frontier for non-invasive cancer diagnosis [197]. In detail, VOCs such as toluene, benzene, styrene, ethanol, methanol, acetaldehyde, formaldehyde, and octanal are present in the breath of people suffering cancer [198] in concentrations higher with respect to the health subject [199].

Recently, Feller et al. presented the design of a biobased carbon nanorods VOC sensor for the effective detection of acetone, ethanol, and methanol for the early diagnosis of cancer [200]. Importantly, the device was prepared via an easy, fast and green approach through the pyrolysis of a renewable carbon source, i.e., castor oil.

Also Sahajwalla et al. have developed a new sensor with sensing performances tailored for VOC biomarker cancer detection [201]. As illustrated in Figure 12, the tool was synthetized using pristine graphene and zinc oxide nanoparticles recovered from spent $\mathrm{Zn}-\mathrm{C}$ batteries. 


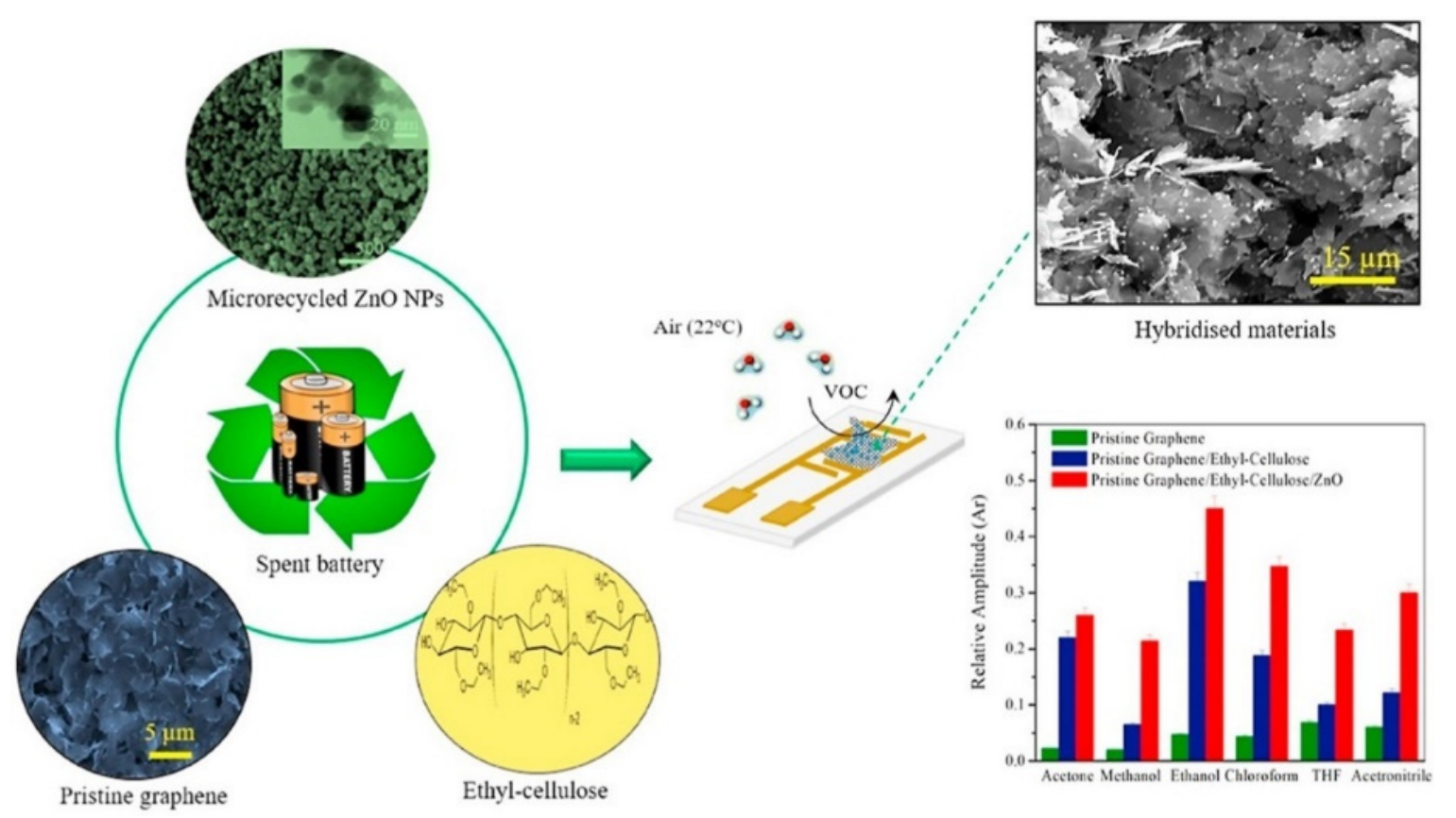

Figure 12. Schematic representation of the preparation of $\mathrm{ZnO}$-based sensors for VOCs detection and cancer diagnosis using spent batteries, Reprinted with permission from ref. [201]. Copyright 2021 Elsevier.

Preliminary tests showed that the recycled $\mathrm{ZnO}$ nanoparticles had good selectivity along with a sensitivity towards chloroform $\left(\mathrm{CHCl}_{3}\right)$ and ethanol at a $5 \mathrm{ppm}$ testing level, a value of concentration often found in patients suffering from cancer.

Another $\mathrm{ZnO}$-based sensor has been reported for the detection of butanone $\left(\mathrm{C}_{4} \mathrm{H}_{8} \mathrm{O}\right)$, a VOC present in the breath of patients with gastric cancer [202]. In particular, a biconelike $\mathrm{ZnO}$ structure was prepared through a microwave-assisted template free method. The structure showed outstanding performances in terms of selectivity, sensitivity, and detection limit $(0.41 \mathrm{ppm})$.

\section{Conclusions: Challenges and Opportunities}

Global warning, overpopulation crisis, the decreasing availability of water, food fraud and adulteration, the overspreading of non-communicative diseases, are just some of the challenges the world is currently facing. In the most recent period, also influenced by important changes caused by the COVID-19 pandemic, society has gained more consciousness about these issues and has started asking its policy makers for relevant responses. Thus, sustainable development has become a primary necessity, not just a desirable eventuality.

Scientists have been undoubtedly among the first suggesting key strategies for a green future. In the field of analytical chemistry, researchers have specifically highlighted the importance of accessing sustainable, innovative, fast, and accurate techniques and technologies for VOCs' analysis alternatives to the traditional tools requiring expensive, long analysis, and that imply the disposal of large volumes of waste (e.g., solvents), such as mass spectrometry, adsorption/atomic emission spectroscopy or chromatography-based techniques (Table 3).

As described throughout this review, in recent years researchers have proposed novel sustainable sensors and biosensors for VOCs' detection for highly relevant applications and for the well-being of society. The monitoring of the toxicity of different environments (e.g., houses and schools), the control of the freshness and quality of foods, especially in meat and fish products, and the diagnosing of different diseases such as diabetes or cancer, are just some of the potential uses of these new devices. 
Table 3. Advantages and disadvantages of classic tools and sustainable sensors and biosensors for the detection of VOCs.

\begin{tabular}{ccc}
\hline & Advantages & Disadvantages \\
\hline $\begin{array}{c}\text { Classic methods (e.g., GC, } \\
\text { HPLC, PTR, etc.) }\end{array}$ & $\begin{array}{c}\text { High specificity; rapid } \\
\text { separations; robust techniques }\end{array}$ & $\begin{array}{c}\text { Matrix effects; high costs; } \\
\text { higher maintenance; } \\
\text { laborious sample preparation }\end{array}$ \\
\hline $\begin{array}{c}\text { Sustainable sensors } \\
\text { and biosensors }\end{array}$ & $\begin{array}{c}\text { Rapid response and recovery } \\
\text { time; inexpensive; high } \\
\text { sensitivity; small size; good } \\
\text { precision; robustness }\end{array}$ & $\begin{array}{c}\text { Temperature and humidity } \\
\text { sensitive; high power } \\
\text { consumption; short lifetime }\end{array}$ \\
\hline
\end{tabular}

Remarkable results have been obtained, but still there are important barriers to overcome, including optimizing the selectivity, the stability, the efficiency and the detection limit of these sensors and biosensors. For example, there are inorganic gases, pathogens, or compounds such as proteins, that can interact with the devices and interfere with their specific sensing actions, affecting selectivity. Thus, these devices are required to differentiate target substances from non-targets, showing high specificity and reducing non-specific interactions. Additionally, most of the sensors and biosensors were developed without performing a deep analysis of the production and utilization costs, which can be higher than the production and utilization costs of classic analytical tools. Finally, it must be highlighted that little effort has been given to deeper explore and investigate the end life of these sensors and biosensors, which should be considered a crucial point in the development of this type of device.

In future development, these issues can be addressed by exploiting the most recent advances in the technologies related to the different components of the sensors and biosensors. For example, the latest results in biotechnology are opening to the possibility of designing highly selective biosensors by tuning the affinity of the biological receptors to selected VOCs thanks to gene editing techniques $[203,204]$. Additionally, progress in microfabrication can lead to a substantial decrease in production costs, to large scale fabrication of nominally identical structures, and to the possibility of integrating different sensors and biosensors [205]. Lastly, to fully attain the sustainable characteristics needed for sustainable development, a life cycle assessment (LCA), claimed to be the best framework for assessing the potential environmental impacts of products [206], must be also determined for all sensors and biosensors before being brought to the market.

Forthcoming optimized VOC sensors and biosensors can be thus employed for the monitoring of thousands of environments and microenvironments by performing analyses at low costs and with high efficiency. This can have a tremendous impact on society, for example, by monitoring the quality of air in sensitive places such as schools and hospitals, or by making possible the massive control of food quality in the food supply chain, breaking down the food waste. The integration of the newest sensors and biosensors with innovative technologies will also potentially expand and integrate their use. For example, in combination with the Internet of Things (IOT), the sensors and biosensors can allow the real time monitoring of VOCs present in different places with communication among devices. This may result in the performing of corrective actions such as the activation of a ventilation mechanism in response to the reaching of a toxic concentration of a VOC in an environment. Additionally, integration with blockchain technology can provide information for producers, distributors and consumers about the origin, production, and traceability of food products within one portable, inexpensive, and compact device.

Author Contributions: Conceptualization, C.M.C. and A.Z.; writing-original draft preparation, C.M.C. and A.Z.; writing-review and editing, C.M.C., E.R., E.E., L.S. and A.Z. All authors have read and agreed to the published version of the manuscript. 
Funding: The authors would like to thank the Spanish Ministry of Economy, Industry and Competitiveness (Ramon y Cajal contract RYC-2015-17109) and Universidad de Córdoba (Predoctoral Grant 2019) for their financial support during this work.

Institutional Review Board Statement: Not applicable.

Data Availability Statement: Not applicable.

Conflicts of Interest: The authors declare no conflict of interest.

\section{References}

1. What Are Volatile Organic Compounds (VOCs)? Available online: https://www.epa.gov/indoor-air-quality-iaq/what-arevolatile-organic-compounds-vocs (accessed on 1 December 2021).

2. VOC. Available online: https://www.eea.europa.eu/themes/air/air-quality/resources/glossary/voc (accessed on 15 December 2021).

3. Menezes, H.C.; Amorim, L.C.A.; Cardeal, Z.L. Sampling and Analytical Methods for Determining VOC in Air by Biomonitoring Human Exposure. Crit. Rev. Environ. Sci. Technol. 2013, 43, 1-39. [CrossRef]

4. Zhang, G.X.; Feizbakhshan, M.; Zheng, S.L.; Hashisho, Z.; Sun, Z.M.; Liu, Y.Y. Effects of properties of minerals adsorbents for the adsorption and desorption of volatile organic compounds (VOC). Appl. Clay Sci. 2019, 173, 88-96. [CrossRef]

5. World Health Organization. Indoor Air Quality: Organic Pollutants. In Proceedings of the WHO Meeting, Berlin, Germany, 23-27 August 1987.

6. Hu, Y.; Li, Z.Y.; Wang, Y.T.; Wang, L.; Zhu, H.T.; Chen, L.; Guo, X.B.; An, C.X.; Jiang, Y.J.; Liu, A.Q. Emission Factors of NOx, SO2, PM and VOCs in Pharmaceuticals, Brick and Food Industries in Shanxi, China. Aerosol Air Qual. Res. 2019, 19, 1785-1797. [CrossRef]

7. Won, S.R.; Ghim, Y.S.; Kim, J.; Ryu, J.; Shim, I.K.; Lee, J. Volatile Organic Compounds in Underground Shopping Districts in Korea. Int. J. Environ. Res. Public Health 2021, 18, 5508. [CrossRef]

8. Lee, H.J.; Lee, K.H.; Kim, D.K. Evaluation and comparison of the indoor air quality in different areas of the hospital. Medicine 2020, 99, e23942. [CrossRef] [PubMed]

9. Lerner, J.E.C.; Gutierrez, M.D.; Mellado, D.; Giuliani, D.; Massolo, L.; Sanchez, E.Y.; Porta, A. Characterization and cancer risk assessment of VOCs in home and school environments in gran La Plata, Argentina. Environ. Sci. Pollut. Res. 2018, 25, 10039-10048. [CrossRef]

10. Jung, C.R.; Nishihama, Y.; Nakayama, S.F.; Tamura, K.; Isobe, T.; Michikawa, T.; Iwai-Shimada, M.; Kobayashi, Y.; Sekiyama, M.; Taniguchi, Y.; et al. Indoor air quality of 5000 households and its determinants. Part B: Volatile organic compounds and inorganic gaseous pollutants in the Japan Environment and Children's study. Environ. Res. 2021, 197, 111135. [CrossRef]

11. Inoue, M.; Mizuguchi, A.; Ueta, I.; Takahashi, K.; Saito, Y. Rapid on-site air sampling with a needle extraction device for evaluating the indoor air environment in school facilities. Anal. Sci. 2013, 29, 519-525. [CrossRef]

12. Adamova, T.; Hradecky, J.; Panek, M. Volatile Organic Compounds (VOCs) from Wood and Wood-Based Panels: Methods for Evaluation, Potential Health Risks, and Mitigation. Polymers 2020, 12, 2289. [CrossRef]

13. Ulker, O.C.; Ulker, O.; Hiziroglu, S. Volatile organic compounds (VOCs) emitted from coated furniture units. Coatings 2021, 11, 806. [CrossRef]

14. Liang, W.H.; Yang, S.; Yang, X.D. Long-Term Formaldehyde Emissions from Medium-Density Fiberboard in a Full-Scale Experimental Room: Emission Characteristics and the Effects of Temperature and Humidity. Environ. Sci. Technol. 2015, 49, 10349-10356. [CrossRef] [PubMed]

15. Rovelli, S.; Cattaneo, A.; Fazio, A.; Spinazze, A.; Borghi, F.; Campagnolo, D.; Dossi, C.; Cavallo, D.M. VOCs measurements in residential buildings: Quantification via thermal desorption and assessment of indoor concentrations in a case-study. Atmosphere 2019, 10, 57. [CrossRef]

16. Yang, F.C.; Wang, Y.; Li, H.L.; Yang, M.M.; Li, T.; Cao, F.F.; Chen, J.M.; Wang, Z. Influence of cloud/fog on atmospheric VOCs in the free troposphere: A case study at Mount Tai in Eastern China. Aerosol Air Qual. Res. 2017, 17, 2401-2412. [CrossRef]

17. Xiang, W.; Zhang, X.Y.; Chen, K.Q.; Fang, J.N.; He, F.; Hu, X.; Tsang, D.C.W.; Ok, Y.S.; Gao, B. Enhanced adsorption performance and governing mechanisms of ball-milled biochar for the removal of volatile organic compounds (VOCs). Chem. Eng. J. 2020, 385, 123842. [CrossRef]

18. Zhu, L.L.; Shen, D.K.; Luo, K.H. A critical review on VOCs adsorption by different porous materials: Species, mechanisms and modification methods. J. Hazard. Mater. 2020, 389, 122102. [CrossRef]

19. Zhu, L.; Deng, B.Q.; Guo, Y. A unified model for VOCs emission/sorption from/on building materials with and without ventilation. Int. J. Heat Mass Transf. 2013, 67, 734-740. [CrossRef]

20. Kang, I.S.; Xi, J.Y.; Hu, H.Y. Photolysis and photooxidation of typical gaseous VOCs by UV Irradiation: Removal performance and mechanisms. Front. Environ. Sci. Eng. 2018, 12, 8. [CrossRef]

21. Deng, B.Q.; Zhang, B.; Qiu, Y.F. Analytical solution of VOCs emission from wet materials with variable thickness. Build. Environ. 2016, 104, 145-151. [CrossRef]

22. Liu, Z.W.; Yan, Y.S.; Liu, T.T.; Zhao, Y.C.; Huang, Q.F.; Huang, Z.C. How to predict emissions of volatile organic compounds from solid building materials? A critical review on mass transfer models. J. Environ. Manag. 2022, 302, 114054. [CrossRef] 
23. Zhang, L.; Zhu, X.Z.; Wang, Z.R.; Zhang, J.; Liu, X.; Zhao, Y. Improved speciation profiles and estimation methodology for VOCs emissions: A case study in two chemical plants in eastern China. Environ. Pollut. 2021, 291, 118192. [CrossRef] [PubMed]

24. Hunt, S.; Grau-Bove, J.; Schofield, E.; Gaisford, S. Effect of polyethylene glycol treatment on acetic acid emissions from wood. Forests 2021, 12, 1629. [CrossRef]

25. Even, M.; Girard, M.; Rich, A.; Hutzler, C.; Luch, A. Emissions of VOCs from polymer-based consumer products: From emission data of real samples to the assessment of inhalation exposure. Front. Public Health 2019, 7, 202. [CrossRef]

26. Jo, S.H.; Lee, M.H.; Kim, K.H.; Kumar, P. Characterization and flux assessment of airborne phthalates released from polyvinyl chloride consumer goods. Environ. Res. 2018, 165, 81-90. [CrossRef]

27. Noguchi, M.; Yamasaki, A. Volatile and semivolatile organic compound emissions from polymers used in commercial products during thermal degradation. Heliyon 2020, 6, e03314. [CrossRef] [PubMed]

28. Zhang, X.F.; Yin, Y.Y.; Wen, J.H.; Huang, S.L.; Han, D.M.; Chen, X.J.; Cheng, J.P. Characteristics, reactivity and source apportionment of ambient volatile organic compounds (VOCs) in a typical tourist city. Atmos. Environ. 2019, 215, 116898. [CrossRef]

29. Liu, Y.H.; Wang, H.L.; Jing, S.G.; Gao, Y.Q.; Peng, Y.R.; Lou, S.R.; Cheng, T.T.; Tao, S.K.; Li, L.; Li, Y.J.; et al. Characteristics and sources of volatile organic compounds (VOCs) in Shanghai during summer: Implications of regional transport. Atmos. Environ. 2019, 215, 116902. [CrossRef]

30. Chin, J.Y.; Batterman, S.A. VOC composition of current motor vehicle fuels and vapors, and collinearity analyses for receptor modeling. Chemosphere 2012, 86, 951-958. [CrossRef] [PubMed]

31. Tampio, E.A.; Blasco, L.; Vainio, M.M.; Kahala, M.M.; Rasi, S.E. Volatile fatty acids (VFAs) and methane from food waste and cow slurry: Comparison of biogas and VFA fermentation processes. Glob. Chang. Biol. Bioenergy 2019, 11, 72-84. [CrossRef]

32. Vivaldo, G.; Masi, E.; Taiti, C.; Caldarelli, G.; Mancuso, S. The network of plants volatile organic compounds. Sci. Rep. 2017, 7, 11050. [CrossRef]

33. Cova, C.M.; Zuliani, A.; Munoz-Batista, M.J.; Luque, R. Efficient Ru-based scrap waste automotive converter catalysts for the continuous-flow selective hydrogenation of cinnamaldehyde. Green Chem. 2019, 21, 4712-4722. [CrossRef]

34. Zuliani, A.; Cova, C.M.; Manno, R.; Sebastian, V.; Romero, A.A.; Luque, R. Continuous flow synthesis of menthol via tandem cyclisation-hydrogenation of citronellal catalysed by scrap catalytic converters. Green Chem. 2020, 22, 379-387. [CrossRef]

35. Brilli, F.; Loreto, F.; Baccelli, I. Exploiting plant volatile organic compounds (VOCs) in agriculture to improve sustainable defense strategies and productivity of crops. Front. Plant Sci. 2019, 10, 264. [CrossRef] [PubMed]

36. Boachon, B.; Lynch, J.H.; Ray, S.; Yuan, J.; Caldo, K.M.P.; Junker, R.R.; Kessler, S.A.; Morgan, J.A.; Dudareva, N. Natural fumigation as a mechanism for volatile transport between flower organs. Nat. Chem. Biol. 2019, 15, 583-588. [CrossRef]

37. Rios-Navarro, A.; Gonzalez, M.; Carazzone, C.; Ramirez, A.M.C. Learning about microbial language: Possible interactions mediated by microbial volatile organic compounds (VOCs) and relevance to understanding Malassezia spp. metabolism. Metabolomics 2021, 17, 39. [CrossRef]

38. D'Onofrio, C.; Knoll, W.; Pelosi, P. Aphid odorant-binding protein 9 is narrowly tuned to linear alcohols and aldehydes of sixteen carbon atoms. Insects 2021, 12, 741. [CrossRef] [PubMed]

39. Capuano, R.; Paba, E.; Mansi, A.; Marcelloni, A.M.; Chiominto, A.; Proietto, A.R.; Zampetti, E.; Macagnano, A.; Lvova, L.; Catini, A.; et al. Aspergillus species discrimination using a gas sensor array. Sensors 2020, 20, 4004. [CrossRef]

40. Weisskopf, L.; Schulz, S.; Garbeva, P. Microbial volatile organic compounds in intra-kingdom and inter-Kingdom interactions. Nat. Rev. Microbiol. 2021, 19, 391-404. [CrossRef] [PubMed]

41. Zou, Z.W.; He, J.Z.; Yang, X.D. An experimental method for measuring VOC emissions from individual human whole-body skin under controlled conditions. Build. Environ. 2020, 181, 107137. [CrossRef]

42. Janssens, E.; van Meerbeeck, J.P.; Lamote, K. Volatile organic compounds in human matrices as lung cancer biomarkers: A systematic review. Crit. Rev. Oncol. Hematol. 2020, 153, 103037. [CrossRef]

43. Course, C.; Watkins, W.J.; Muller, C.; Odd, D.; Kotecha, S.; Chakraborty, M. Volatile organic compounds as disease predictors in newborn infants: A systematic review. J. Breath Res. 2021, 15, 024002. [CrossRef] [PubMed]

44. Gouzerh, F.; Bessiere, J.M.; Ujvari, B.; Thomas, F.; Dujon, A.M.; Dormont, L. Odors and cancer: Current status and future directions. Biochim. Et Biophys. Acta-Rev. Cancer 2022, 1877, 188644. [CrossRef]

45. Xiang, L.J.; Wu, S.H.; Hua, Q.L.; Bao, C.Y.; Liu, H. Volatile organic compounds in human exhaled breath to diagnose gastrointestinal cancer: A meta-analysis. Front. Oncol. 2021, 11, 269. [CrossRef] [PubMed]

46. Corsini, L.; Castro, R.; Barroso, C.G.; Duran-Guerrero, E. Characterization by gas chromatography-olfactometry of the most odour-active compounds in Italian balsamic vinegars with geographical indication. Food Chem. 2019, 272, 702-708. [CrossRef] [PubMed]

47. Aznar, M.; Domeno, C.; Osorio, J.; Nerin, C. Release of volatile compounds from cooking plastic bags under different heating sources. Food Packag. Shelf Life 2020, 26, 100552. [CrossRef]

48. Zhou, T.; Feng, Y.Z.; Thomas-Danguin, T.; Zhao, M.M. Enhancement of saltiness perception by odorants selected from Chinese soy sauce: A gas chromatography/olfactometry-associated taste study. Food Chem. 2021, 335, 127664. [CrossRef]

49. Kumar, S.; Huang, J.Z.; Abbassi-Ghadi, N.; Spanel, P.; Smith, D.; Hanna, G.B. Selected Ion flow tube mass spectrometry analysis of exhaled breath for volatile organic compound profiling of esophago-gastric cancer. Anal. Chem. 2013, 85, 6121-6128. [CrossRef]

50. Yuan, B.; Koss, A.R.; Warneke, C.; Coggon, M.; Sekimoto, K.; de Gouw, J.A. Proton-transfer-reaction mass spectrometry: Applications in atmospheric sciences. Chem. Rev. 2017, 117, 13187-13229. [CrossRef] 
51. Biasioli, F.; Yeretzian, C.; Gasperi, F.; Mark, T.D. PTR-MS monitoring of VOCs and BVOCs in food science and technology. Trac-Trends Anal. Chem. 2011, 30, 968-977. [CrossRef]

52. Spinelle, L.; Gerboles, M.; Kok, G.; Persijn, S.; Sauerwald, T. Review of portable and low-cost sensors for the ambient air monitoring of benzene and other volatile organic compounds. Sensors 2017, 17, 1520. [CrossRef]

53. Zheng, L.F.; Zhang, C.; Ma, J.; Hong, S.H.; She, Y.X.; Abd El-Aty, A.M.; He, Y.H.; Yu, H.L.; Liu, H.J.; Wang, J. Fabrication of a highly sensitive electrochemical sensor based on electropolymerized molecularly imprinted polymer hybrid nanocomposites for the determination of 4-nonylphenol in packaged milk samples. Anal. Biochem. 2018, 559, 44-50. [CrossRef]

54. Rasheed, T.; Hassan, A.A.; Kausar, F.; Sher, F.; Bilal, M.; Iqbal, H.M.N. Carbon nanotubes assisted analytical detectionSensing/delivery cues for environmental and biomedical monitoring. Trac-Trends Anal. Chem. 2020, 132, 116066. [CrossRef]

55. Fazio, E.; Spadaro, S.; Corsaro, C.; Neri, G.; Leonardi, S.G.; Neri, F.; Lavanya, N.; Sekar, C.; Donato, N. Metal-oxide based nanomaterials: Synthesis, characterization and their applications in electrical and electrochemical sensors. Sensors 2021, 21, 2494. [CrossRef]

56. El Kazzy, M.; Weerakkody, J.S.; Hurot, C.; Mathey, R.; Buhot, A.; Scaramozzino, N.; Hou, Y.X. An overview of artificial olfaction systems with a focus on surface plasmon resonance for the analysis of volatile organic compounds. Biosensors 2021, 11, 244. [CrossRef] [PubMed]

57. Dobrzyniewski, D.; Szulczynski, B.; Dymerski, T.; Gebicki, J. Development of gas sensor array for methane reforming process monitoring. Sensors 2021, 21, 4983. [CrossRef]

58. Justino, C.I.L.; Duarte, A.C.; Rocha-Santos, T.A.P. Critical overview on the application of sensors and biosensors for clinical analysis. Trac-Trends Anal. Chem. 2016, 85, 36-60. [CrossRef] [PubMed]

59. Ratajczak, K.; Stobiecka, M. High-performance modified cellulose paper-based biosensors for medical diagnostics and early cancer screening: A concise review. Carbohydr. Polym. 2020, 229, 115463. [CrossRef] [PubMed]

60. Cesewski, E.; Johnson, B.N. Electrochemical biosensors for pathogen detection. Biosens. Bioelectron. 2020, 159, 112214. [CrossRef]

61. Majdinasab, M.; Mishra, R.K.; Tang, X.Q.; Marty, J.L. Detection of antibiotics in food: New achievements in the development of biosensors. Trac-Trends Anal. Chem. 2020, 127, 115883. [CrossRef]

62. Bhalla, N.; Pan, Y.W.; Yang, Z.G.; Payam, A.F. Opportunities and challenges for biosensors and nanoscale analytical tools for pandemics: COVID-19. ACS Nano 2020, 14, 7783-7807. [CrossRef]

63. Majhi, S.M.; Mirzaei, A.; Kim, H.W.; Kim, S.S.; Kim, T.W. Recent advances in energy-saving chemiresistive gas sensors: A review Nano Energy 2021, 79, 105369. [CrossRef] [PubMed]

64. Jiang, Y.C.; Yin, S.; Dong, J.W.; Kaynak, O. A Review on soft sensors for monitoring, control, and optimization of industrial processes. IEEE Sens. J. 2021, 21, 12868-12881. [CrossRef]

65. Mani, V.; Beduk, T.; Khushaim, W.; Ceylan, A.E.; Timur, S.; Wolfbeis, O.S.; Salama, K.N. Electrochemical sensors targeting salivary biomarkers: A comprehensive review. Trac-Trends Anal. Chem. 2021, 135, 116164. [CrossRef]

66. Tajik, S.; Beitollahi, H.; Nejad, F.G.; Dourandish, Z.; Khalilzadeh, M.A.; Jang, H.W.; Venditti, R.A.; Varma, R.S.; Shokouhimehr, M. Recent developments in polymer nanocomposite-based electrochemical sensors for detecting environmental pollutants. Ind. Eng. Chem. Res. 2021, 60, 1112-1136. [CrossRef]

67. Nykamp, H. A transition to green buildings in Norway. Environ. Innov. Soc. Transit. 2017, 24, 83-93. [CrossRef]

68. Kemp-Benedict, E. Investing in a Green Transition. Ecol. Econ. 2018, 153, 218-236. [CrossRef]

69. Yang, Y.C.; Nie, P.Y.; Huang, J.B. The optimal strategies for clean technology to advance green transition. Sci. Total Environ. 2020, 716, 134439. [CrossRef]

70. Bogovic, N.D.; Grdic, Z.S. Transitioning to a green economy-possible effects on the croatian economy. Sustainability 2020, 12,9342 [CrossRef]

71. Sharpe, S.A.; Martinez-Fernandez, C.M. The Implications of green employment: Making a just transition in ASEAN. Sustainability 2021, 13, 7389. [CrossRef]

72. Ohnesorge, L.; Rogge, E. Europe's green policy: Towards a climate neutral economy by way of investors' choice. Eur. Co. Law 2021, 18, 34-39.

73. Zuliani, A.; Cova, C.M. Green synthesis of heterogeneous visible-light-active photocatalysts: Recent advances. Photochem 2021, 1,147-166. [CrossRef]

74. Green Transition. Available online: https://ec.europa.eu/reform-support/what-we-do/green-transition_en (accessed on 25 November 2021).

75. Zuliani, A.; Balu, A.M.; Luque, R. Efficient and Environmentally friendly microwave-assisted synthesis of catalytically active magnetic metallic Ni nanoparticles. ACS Sustain. Chem. Eng. 2017, 5, 11584-11587. [CrossRef]

76. Zuliani, A.; Ranjan, P.; Luque, R.; Van der Eycken, E.V. Heterogeneously catalyzed synthesis of imidazolones via cycloisomerizations of propargylic ureas using Ag and Au/AI SBA-15 systems. ACS Sustain. Chem. Eng. 2019, 7, 5568-5575. [CrossRef]

77. Cova, C.M.; Zuliani, A.; Manno, R.; Sebastian, V.; Luque, R. Scrap waste automotive converters as efficient catalysts for the continuous-flow hydrogenations of biomass derived chemicals. Green Chem. 2020, 22, 1414-1423. [CrossRef]

78. Zuliani, A.; Cano, M.; Calsolaro, F.; Puente Santiago, A.R.; Giner-Casares, J.J.; Rodríguez-Castellón, E.; Berlier, G.; Cravotto, G.; Martina, K.; Luque, R. Improving the electrocatalytic performance of sustainable Co/carbon materials for the oxygen evolution reaction by ultrasound and microwave assisted synthesis. Sustain. Energy Fuels 2021, 5, 720-731. [CrossRef] 
79. Ivars-Barcelo, F.; Zuliani, A.; Fallah, M.; Mashkour, M.; Rahimnejad, M.; Luque, R. Novel applications of microbial fuel cells in sensors and biosensors. Appl. Sci. 2018, 8, 1184. [CrossRef]

80. Ghosh, R.; Gardner, J.W.; Guha, P.K. Air pollution monitoring using near room temperature resistive gas sensors: A review. IEEE Trans. Electron Devices 2019, 66, 3254-3264. [CrossRef]

81. Masikini, M.; Chowdhury, M.; Nemraoui, O. Review-metal oxides: Application in exhaled breath acetone chemiresistive sensors. J. Electrochem. Soc. 2020, 167, 037537. [CrossRef]

82. Wang, J.X.; Zhou, Q.; Peng, S.D.; Xu, L.N.; Zeng, W. Volatile organic compounds gas sensors based on molybdenum oxides: A mini review. Front. Chem. 2020, 8, 339. [CrossRef] [PubMed]

83. Li, H.Y.; Zhao, S.N.; Zang, S.Q.; Li, J. Functional metal-organic frameworks as effective sensors of gases and volatile compounds. Chem. Soc. Rev. 2020, 49, 6364-6401. [CrossRef] [PubMed]

84. Li, B.L.; Zhou, Q.; Peng, S.D.; Liao, Y.M. Recent advances of $\mathrm{SnO}_{2}$-based sensors for detecting volatile organic compounds. Front Chem. 2020, 8, 321. [CrossRef]

85. Tholl, D.; Hossain, O.; Weinhold, A.; Rose, U.S.R.; Wei, Q.S. Trends and applications in plant volatile sampling and analysis. Plant J. 2021, 106, 314-325. [CrossRef]

86. Zeng, H.; Zhang, G.Z.; Nagashima, K.; Takahashi, T.; Hosomi, T.; Yanagida, T. Metal-oxide nanowire molecular sensors and their promises. Chemosensors 2021, 9, 41. [CrossRef]

87. Tomic, M.; Setka, M.; Vojkuvka, L.; Vallejos, S. VOCs sensing by metal oxides, conductive polymers, and carbon-based materials. Nanomaterials 2021, 11, 552. [CrossRef]

88. Pelosi, P.; Mastrogiacomo, R.; Iovinella, I.; Tuccori, E.; Persaud, K.C. Structure and biotechnological applications of odorantbinding proteins. Appl. Microbiol. Biotechnol. 2014, 98, 61-70. [CrossRef]

89. Wasilewski, T.; Szulczynski, B.; Wojciechowski, M.; Kamysz, W.; Gebicki, J. Determination of long-chain aldehydes using a novel quartz crystal microbalance sensor based on a biomimetic peptide. Microchem. J. 2020, 154, 104509. [CrossRef]

90. Magna, G.; Muduganti, M.; Stefanelli, M.; Sivalingam, Y.; Zurlo, F.; Di Bartolomeo, E.; Catini, A.; Martinelli, E.; Paolesse, R.; Di Natale, C. Light-activated porphyrinoid-capped nanoparticles for gas sensing. ACS Appl. Nano Mater. 2021, 4, 414-424. [CrossRef]

91. Gong, Y.; Wei, Y.J.; Cheng, J.H.; Jiang, T.Y.; Chen, L.; Xu, B. Health risk assessment and personal exposure to Volatile Organic Compounds (VOCs) in metro carriages-A case study in Shanghai, China. Sci. Total Environ. 2017, 574, 1432-1438. [CrossRef] [PubMed]

92. Soni, V.; Singh, P.; Shree, V.; Goel, V. Effects of VOCs on human health. In Air Pollution and Control. Energy, Environment, and Sustainability; Springer: Singapore, 2018; pp. 119-142. [CrossRef]

93. Meciarova, L.; Vilcekova, S.; Burdova, E.K.; Kiselak, J. Factors effecting the total volatile organic compound (TVOC) concentrations in Slovak households. Int. J. Environ. Res. Public Health 2017, 14, 1443. [CrossRef] [PubMed]

94. Yang, S.; Yang, X.D.; Licina, D. Emissions of volatile organic compounds from interior materials of vehicles. Build. Environ. 2020, 170, 1443. [CrossRef]

95. Harb, P.; Locoge, N.; Thevenet, F. Emissions and treatment of VOCs emitted from wood-based construction materials: Impact on indoor air quality. Chem. Eng. J. 2018, 354, 641-652. [CrossRef]

96. Caron, F.; Guichard, R.; Robert, L.; Verriele, M.; Thevenet, F. Behaviour of individual VOCs in indoor environments: How ventilation affects emission from materials. Atmos. Environ. 2020, 243, 117713. [CrossRef]

97. Heroux, M.E.; Gauvin, D.; Gilbert, N.L.; Guay, M.; Dupuis, G.; Legris, M.; Levesque, B. Housing characteristics and indoor concentrations of selected volatile organic compounds (VOCs) in Quebec City, Canada. Indoor Built Environ. 2008, 17, 128-137. [CrossRef]

98. Toxicological Profiles. Available online: https://www.atsdr.cdc.gov/toxprofiledocs/index.html (accessed on 3 December 2021).

99. Lai, X.Y.; Cao, K.; Shen, G.X.; Xue, P.; Wang, D.; Hu, F.; Zhang, J.L.; Yang, Q.F.; Wang, X.Z. Ordered mesoporous NiFe ${ }_{2} \mathrm{O}_{4}$ with ultrathin framework for low-ppb toluene sensing. Sci. Bull. 2018, 63, 187-193. [CrossRef]

100. Cui, F.H.; Wang, G.; Yu, D.W.; Gan, X.D.; Tian, Q.H.; Guo, X.Y. Towards "zero waste" extraction of nickel from scrap nickel-based superalloy using magnesium. J. Clean. Prod. 2020, 262, 121275. [CrossRef]

101. Li, H.R.; Li, Y.; Cheng, H.L.; Yang, Q.R.; Xiong, J.H.; Ma, Y.J.; Ding, L.W.; Zeng, C.H. Lanthanide Metal-organic frameworks as luminescent sensor for toluene. J. Inorg. Organomet. Polym. Mater. 2020, 30, 2645-2653. [CrossRef]

102. Wang, J.L.; Wu, Z.L.; Chen, S.H.; Yuan, R.; Dong, L. A novel multifunctional fluorescent sensor based on N/S co-doped carbon dots for detecting $\mathrm{Cr}$ (VI) and toluene. Microchem. J. 2019, 151, 104246. [CrossRef]

103. Sarris, D.; Galiotou-Panayotou, M.; Koutinas, A.A.; Komaitis, M.; Papanikolaou, S. Citric acid, biomass and cellular lipid production by Yarrowia lipolytica strains cultivated on olive mill wastewater-based media. J. Chem. Technol. Biotechnol. 2011, 86, 1439-1448. [CrossRef]

104. Zhong, Z.; Fritzsche, M.; Pieper, S.B.; Wood, T.K.; Lear, K.L.; Dandy, D.S.; Reardon, K.F. Fiber optic monooxygenase biosensor for toluene concentration measurement in aqueous samples. Biosens. Bioelectron. 2011, 26, 2407-2412. [CrossRef] [PubMed]

105. Durmaz, M.; Acikbas, Y.; Bozkurt, S.; Capan, R.; Erdogan, M.; Ozkaya, C. A novel Calix 4 arene thiourea decorated with 2-(2-aminophenyl)benzothiazole moiety as highly selective chemical gas sensor for dichloromethane vapor. ChemistrySelect 2021, 6, 4670-4676. [CrossRef] 
106. Kim, E.B.; Abdullah; Ameen, S.; Akhtar, M.S.; Shin, H.S. Environment-friendly and highly sensitive dichloromethane chemical sensor fabricated with ZnO nanopyramids-modified electrode. J. Taiwan Inst. Chem. Eng. 2019, 102, 143-152. [CrossRef]

107. Wang, H.Y.; Zhan, S.P.; Wu, X.F.; Wu, L.Q.; Liu, Y.X. Nanoporous fluorescent sensor based on upconversion nanoparticles for the detection of dichloromethane with high sensitivity. RSC Adv. 2021, 11, 565-571. [CrossRef]

108. Plekhanova, Y.V.; Firsova, Y.E.; Doronina, N.V.; Trotsenko, Y.A.; Reshetilov, A.N. Aerobic methylobacteria as the basis for a biosensor for dichloromethane detection. Appl. Biochem. Microbiol. 2013, 49, 188-193. [CrossRef]

109. Weston-Green, K.; Clunas, H.; Naranjo, C.J. A review of the potential use of pinene and linalool as terpene-based medicines for brain health: Discovering novel therapeutics in the flavours and fragrances of cannabis. Front. Psychiatry 2021, $12,1309$. [CrossRef]

110. Wen, T.; Sang, M.X.; Wang, M.L.; Han, L.B.; Gong, Z.L.; Tang, X.H.; Long, X.Z.; Xiong, H.; Peng, H.L. Rapid detection of d-limonene emanating from citrus infestation by Bactrocera dorsalis (Hendel) using a developed gas-sensing system based on QCM sensors coated with ethyl cellulose. Sens. Actuators B Chem. 2021, 328, 129048. [CrossRef]

111. Li, B.W.; Xu, C.Q.; Liu, L.; Yu, J.; Fan, Y.M. Facile and sustainable etherification of ethyl cellulose towards excellent UV blocking and fluorescence properties. Green Chem. 2021, 23, 479-489. [CrossRef]

112. Hawari, H.F.; Samsudin, N.M.; Shakaff, A.Y.M.; Wahab, Y.; Hashim, U.; Zakaria, A.; Ghani, S.A.; Ahmad, M.N. Highly selective molecular imprinted polymer (MIP) based sensor array using interdigitated electrode (IDE) platform for detection of mango ripeness. Sens. Actuators B Chem. 2013, 187, 434-444. [CrossRef]

113. Wu, Y.; Shetty, M.; Zhang, K.; Dauenhauer, P.J. Sustainable hybrid route to renewable methacrylic acid via biomass-derived citramalate. ACS Eng. Au 2021. [CrossRef]

114. Hui, K.S.; Chao, C.Y.H. Synthesis of MCM-41 from coal fly ash by a green approach: Influence of synthesis pH. J. Hazard. Mater. 2006, 137, 1135-1148. [CrossRef]

115. Abu-Zied, B.M.; Alam, M.M.; Asiri, A.M.; Schwieger, W.; Rahman, M.M. Fabrication of 1,2-dichlorobenzene sensor based on mesoporous MCM-41 material. Colloids Surf. A Physicochem. Eng. Asp. 2019, 562, 161-169. [CrossRef]

116. Feng, L.; Dong, C.L.; Li, M.F.; Li, L.X.; Jiang, X.; Gao, R.; Wang, R.J.; Zhang, L.J.; Ning, Z.L.; Gao, D.J.; et al. Terbium-based metal-organic frameworks: Highly selective and fast respond sensor for styrene detection and construction of molecular logic gate. J. Hazard. Mater. 2020, 388, 121816. [CrossRef]

117. Alonso, S.; Navarro-Llorens, J.M.; Tormo, A.; Perera, J. Construction of a bacterial biosensor for styrene. J. Biotechnol. 2003, 102, 301-306. [CrossRef]

118. Yuan, H.Y.; Aljneibi, S.; Yuan, J.R.; Wang, Y.X.; Liu, H.; Fang, J.; Tang, C.H.; Yan, X.H.; Cai, H.; Gu, Y.D.; et al. ZnO nanosheets abundant in oxygen vacancies derived from metal-organic frameworks for ppb-level gas sensing. Adv. Mater. 2019, 31, e1807161. [CrossRef]

119. Jo, Y.K.; Jeong, S.Y.; Moon, Y.K.; Jo, Y.M.; Yoon, J.W.; Lee, J.H. Exclusive and ultrasensitive detection of formaldehyde at room temperature using a flexible and monolithic chemiresistive sensor. Nat. Commun. 2021, 12, 4955. [CrossRef] [PubMed]

120. Hu, J.Y.; Chen, X.Q.; Zhang, Y. Batch fabrication of formaldehyde sensors based on $\mathrm{LaFeO}_{3}$ thin film with ppb-level detection limit. Sens. Actuators B Chem. 2021, 349, 130738. [CrossRef]

121. Xu, L.; Ge, M.Y.; Zhang, F.; Huang, H.J.; Sun, Y.; He, D.N. Nanostructured of $\mathrm{SnO}_{2} / \mathrm{NiO}$ composite as a highly selective formaldehyde gas sensor. J. Mater. Res. 2020, 35, 3079-3090. [CrossRef]

122. Kang, Z.J.; Zhang, D.Z.; Li, T.T.; Liu, X.H.; Song, X.S. Polydopamine-modified $\mathrm{SnO}_{2}$ nanofiber composite coated QCM gas sensor for high-performance formaldehyde sensing. Sens. Actuators B Chem. 2021, 345, 130299. [CrossRef]

123. Sun, Y.H.; Wang, J.; Du, H.Y.; Li, X.G.; Wang, C.; Hou, T.Y. Formaldehyde gas sensors based on SnO2/ZSM-5 zeolite composite nanofibers. J. Alloys Compd. 2021, 868, 159140. [CrossRef]

124. Chang, H.K.; Ko, D.S.; Cho, D.H.; Kim, S.; Lee, H.N.; Lee, H.S.; Kim, H.J.; Park, T.J.; Park, Y.M. Enhanced response of the photoactive gas sensor on formaldehyde using porous $\mathrm{SnO}_{2} @ \mathrm{TiO}_{2}$ heterostructure driven by gas-flow thermal evaporation and atomic layer deposition. Ceram. Int. 2021, 47, 5985-5992. [CrossRef]

125. Jali, M.H.; Rahim, H.R.A.; Johari, M.A.M.; Ali, U.U.M.; Johari, S.H.; Mohamed, H.; Harun, S.W.; Yasin, M. Formaldehyde sensor with enhanced performance using microsphere resonator-coupled ZnO nanorods coated glass. Opt. Laser Technol. 2021, 139, 106853. [CrossRef]

126. Liu, J.; Chen, Y.; Zhang, H.Y. Study of highly sensitive formaldehyde sensors based on $\mathrm{ZnO} / \mathrm{CuO}$ heterostructure via the sol-gel method. Sensors 2021, 21, 4685. [CrossRef]

127. Khojier, K. Preparation and investigation of Al-doped $\mathrm{ZnO}$ thin films as a formaldehyde sensor with extremely low detection limit and considering the effect of RH. Mater. Sci. Semicond. Process. 2021, 121, 105283. [CrossRef]

128. Huang, J.Y.; Liang, H.; Ye, J.X.; Jiang, D.T.; Sun, Y.L.; Li, X.J.; Geng, Y.F.; Wang, J.Q.; Qian, Z.F.; Du, Y. Ultrasensitive formaldehyde gas sensor based on Au-loaded $\mathrm{ZnO}$ nanorod arrays at low temperature. Sens. Actuators B Chem. 2021, 346, 130568. [CrossRef]

129. Zheng, Q.Y.; Zhang, H.; Liu, J.L.; Xiao, L.H.; Ao, Y.H.; Li, M. High porosity fluorescent aerogel with new molecular probes for formaldehyde gas sensors. Microporous Mesoporous Mater. 2021, 325, 111208. [CrossRef]

130. Gautam, V.; Kumar, A.; Kumar, R.; Jain, V.K.; Nagpal, S. Silicon nanowires/reduced graphene oxide nanocomposite based novel sensor platform for detection of cyclohexane and formaldehyde. Mater. Sci. Semicond. Process. 2021, 123, 105571. [CrossRef] 
131. Wang, J.L.; Shang, J.H.; Guo, Y.J.; Jiang, Y.Y.; Xiong, W.K.; Li, J.S.; Yang, X.; Torun, H.; Fu, Y.Q.; Zu, X.T. Hydrophobic metal organic framework for enhancing performance of acoustic wave formaldehyde sensor based on polyethyleneimine and bacterial cellulose nanofilms. J. Mater. Sci. Mater. Electron. 2021, 32, 18551-18564. [CrossRef]

132. Padmalaya, G.; Vardhan, K.H.; Kumar, P.S.; Ali, M.A.; Chen, T.W. A disposable modified screen-printed electrode using egg white/ $\mathrm{ZnO}$ rice structured composite as practical tool electrochemical sensor for formaldehyde detection and its comparative electrochemical study with Chitosan/ZnO nanocomposite. Chemosphere 2022, 288, 132560. [CrossRef]

133. Tsuchiya, K.; Furusawa, H.; Nomura, A.; Matsui, H.; Nihei, M.; Tokito, S. Formaldehyde detection by a combination of formaldehyde dehydrogenase and chitosan on a sensor based on an organic field-effect transistor. Technologies $2019,7,48$. [CrossRef]

134. Vanderroost, M.; Ragaert, P.; Devlieghere, F.; De Meulenaer, B. Intelligent food packaging: The next generation. Trends Food Sci. Technol. 2014, 39, 47-62. [CrossRef]

135. Shao, P.; Liu, L.M.; Yu, J.H.; Lin, Y.; Gao, H.Y.; Chen, H.J.; Sun, P.L. An overview of intelligent freshness indicator packaging for food quality and safety monitoring. Trends Food Sci. Technol. 2021, 118, 285-296. [CrossRef]

136. Sohail, M.; Sun, D.W.; Zhu, Z.W. Recent developments in intelligent packaging for enhancing food quality and safety. Crit. Rev. Food Sci. Nutr. 2018, 58, 2650-2662. [CrossRef]

137. Azeredo, H.M.C.; Souza Correa, D. Smart choices: Mechanisms of intelligent food packaging. Curr. Res. Food Sci. 2021, 4, 932-936. [CrossRef] [PubMed]

138. Shukla, V.; Kandeepan, G.; Vishnuraj, M.R.; Soni, A. Anthocyanins based indicator sensor for intelligent packaging application. Agric. Res. 2016, 5, 205-209. [CrossRef]

139. Nguyen, L.H.; Naficy, S.; McConchie, R.; Dehghani, F.; Chandrawati, R. Polydiacetylene-based sensors to detect food spoilage at low temperatures. J. Mater. Chem. C 2019, 7, 1919-1926. [CrossRef]

140. Hashim, S.B.H.; Elrasheid Tahir, H.; Liu, L.; Zhang, J.; Zhai, X.; Ali Mahdi, A.; Nureldin Awad, F.; Hassan, M.M.; Xiaobo, Z.; Jiyong, S. Intelligent colorimetric $\mathrm{pH}$ sensoring packaging films based on sugarcane wax/agar integrated with butterfly pea flower extract for optical tracking of shrimp freshness. Food Chem. 2021, 373, 131514. [CrossRef] [PubMed]

141. Moustafa, H.; Morsy, M.; Ateia, M.A.; Abdel-Haleem, F.M. Ultrafast response humidity sensors based on polyvinyl chloride/graphene oxide nanocomposites for intelligent food packaging. Sens. Actuators A-Phys. 2021, 331, 112918. [CrossRef]

142. Abou Saoud, W.; Assadi, A.A.; Kane, A.; Jung, A.V.; Le Cann, P.; Gerard, A.; Bazantay, F.; Bouzaza, A.; Wolbert, D. Integrated process for the removal of indoor VOCs from food industry manufacturing: Elimination of Butane-2,3-dione and Heptan-2-one by cold plasma-photocatalysis combination. J. Photochem. Photobiol. A Chem. 2020, 386, 112071. [CrossRef]

143. Zhai, X.; Wang, X.; Zhang, J.; Yang, Z.; Sun, Y.; Li, Z.; Huang, X.; Holmes, M.; Gong, Y.; Povey, M.; et al. Extruded low density polyethylene-curcumin film: A hydrophobic ammonia sensor for intelligent food packaging. Food Packag. Shelf Life 2020, 26, 100595. [CrossRef]

144. Reji, R.P.; Marappan, G.; Sivalingam, Y.; Surya, V.J. VOCs adsorption induced surface potential changes on phthalocyanines: A combined experimental and theoretical approach towards food freshness monitoring. Mater. Lett. 2022, 306, 130945. [CrossRef]

145. Wang, A.; Stancik, C.M.; Yin, Y.; Wu, J.; Duncan, S.E. Performance of cost-effective PET packaging with light protective additives to limit photo-oxidation in UHT milk under refrigerated LED-lighted storage condition. Food Packag. Shelf Life 2022, $31,100773$. [CrossRef]

146. Preis, S.; Klauson, D.; Gregor, A. Potential of electric discharge plasma methods in abatement of volatile organic compounds originating from the food industry. J. Environ. Manag. 2013, 114, 125-138. [CrossRef]

147. Fortin, C.; Goodwin, H.L.; Thomsen, M. Consumer attitudes toward freshness indicators on perishable food products. J. Food Distrib. Res. 2009, 40,1-15.

148. Park, Y.W.; Kim, S.M.; Lee, J.Y.; Jang, W. Application of biosensors in smart packaging. Mol. Cell. Toxicol. 2015, 11, 277-285. [CrossRef]

149. Kuswandi, B.; Damayanti, F.; Abdullah, A.; Heng, L.Y. Simple and low-cost on-package sticker sensor based on litmus paper for real-time monitoring of beef freshness. J. Math. Fundam. Sci. 2015, 47, 236-251. [CrossRef]

150. Alessandroni, L.; Caprioli, G.; Faiella, F.; Fiorini, D.; Galli, R.; Huang, X.H.; Marinelli, G.; Nzekoue, F.; Ricciutelli, M.; Scortichini, S.; et al. A shelf-life study for the evaluation of a new biopackaging to preserve the quality of organic chicken meat. Food Chem. 2022, 371, 131134. [CrossRef] [PubMed]

151. Sankaran, S.; Panigrahi, S.; Mallik, S. Odorant binding protein based biomimetic sensors for detection of alcohols associated with Salmonella contamination in packaged beef. Biosens. Bioelectron. 2011, 26, 3103-3109. [CrossRef] [PubMed]

152. Sankaran, S.; Panigrahi, S.; Mallik, S. Olfactory receptor based piezoelectric biosensors for detection of alcohols related to food safety applications. Sens. Actuators B Chem. 2011, 155, 8-18. [CrossRef]

153. Panigrahi, S.; Sankaran, S.; Mallik, S.; Gaddam, B.; Hanson, A.A. Olfactory receptor-based polypeptide sensor for acetic acid VOC detection. Mater. Sci. Eng. C Mater. Biol. Appl. 2012, 32, 1307-1313. [CrossRef] [PubMed]

154. Han, D.Q. Sol-gel autocombustion synthesis of zinc oxide foam decorated with holes and its use as acetic acid gas sensor at sub-ppm level. Ceram. Int. 2020, 46, 3304-3310. [CrossRef]

155. Senapati, M.; Sahu, P.P. Meat quality assessment using Au patch electrode Ag-SnO2/SiO2/Si MIS capacitive gas sensor at room temperature. Food Chem. 2020, 324, 126893. [CrossRef]

156. ACGIH. Available online: https://www.acgih.org/ (accessed on 20 November 2021). 
157. Kim, G.; Cho, B.; Oh, S.H.; Kim, K. Feasibility study for the evaluation of chicken meat storage time using surface acoustic wave sensor. J. Biosyst. Eng. 2020, 45, 261-271. [CrossRef]

158. Chow, C.-F. Bimetallic-based food sensors for meat spoilage: Effects of the accepting metallic unit in Fe(II)-C N-M-A (M-A $=\mathrm{Pt}(\mathrm{II})$ or $\mathrm{Au}(\mathrm{I}))$ on device selectivity and sensitivity. Food Chem. 2019, 300, 125190. [CrossRef] [PubMed]

159. Odeyemi, O.A.; Burke, C.M.; Bolch, C.C.J.; Stanley, R. Seafood spoilage microbiota and associated volatile organic compounds at different storage temperatures and packaging conditions. Int. J. Food Microbiol. 2018, 280, 87-99. [CrossRef] [PubMed]

160. Perillo, P.M.; Rodriguez, D.F. Low temperature trimethylamine flexible gas sensor based on $\mathrm{TiO}_{2}$ membrane nanotubes. J. Alloy. Compd. 2016, 657, 765-769. [CrossRef]

161. Yang, T.Y.; Du, L.Y.; Zhai, C.B.; Li, Z.F.; Zhao, Q.; Luo, Y.; Xing, D.J.; Zhang, M.Z. Ultrafast response and recovery trimethylamine sensor based on alpha- $\mathrm{Fe}_{2} \mathrm{O}_{3}$ snowflake-like hierarchical architectures. J. Alloy. Compd. 2017, 718, 396-404. [CrossRef]

162. Liu, L.K.; Fu, S.; Lv, X.; Yue, L.L.; Fan, L.; Yu, H.T.; Gao, X.L.; Zhu, W.B.; Zhang, W.; Li, X.; et al. A gas sensor with Fe ${ }_{2} \mathrm{O}_{3}$ nanospheres based on trimethylamine detection for the rapid assessment of spoilage degree in fish. Front. Bioeng. Biotechnol. 2020, 8, 567584. [CrossRef] [PubMed]

163. Shen, J.; Xu, S.; Zhao, C.; Qiao, X.; Liu, H.; Zhao, Y.; Wei, J.; Zhu, Y. Bimetallic Au@Pt nanocrystal sensitization mesoporous $\alpha-\mathrm{FeO}_{3}$ hollow nanocubes for highly sensitive and rapid detection of fish freshness at low temperature. ACS Appl. Mater. Interfaces 2021, 13, 57597-57608. [CrossRef]

164. Lv, R.Q.; Huang, X.Y.; Ye, W.T.; Aheto, J.H.; Xu, H.X.; Dai, C.X.; Tian, X.Y. Research on the reaction mechanism of colorimetric sensor array with characteristic volatile gases-TMA during fish storage. J. Food Process Eng. 2019, 42, e12952. [CrossRef]

165. Sun, Y.; Wen, J.W.; Chen, Z.J.; Qiu, S.B.; Wang, Y.X.; Yin, E.Q.; Li, H.B.; Liu, X.H. Non-destructive and rapid method for monitoring fish freshness of grass carp based on printable colorimetric paper sensor in modified atmosphere packaging. Food Anal. Methods 2021, 1-11. [CrossRef]

166. Capello, C.; Trevisol, T.C.; Pelicioli, J.; Terrazas, M.B.; Monteiro, A.R.; Valencia, G.A. Preparation and Characterization of Colorimetric Indicator Films Based on Chitosan/Polyvinyl Alcohol and Anthocyanins from Agri-Food Wastes. J. Polym. Environ. 2021, 29, 1616-1629. [CrossRef]

167. Lai, F.Y.; Yang, J.L.; Huang, R.R.; Wang, Z.L.; Tang, J.Q.; Zhang, M.L.; Miao, R.; Fang, Y. Nondestructive evaluation of fish freshness through nanometer-thick fluorescence-based amine-sensing films. ACS Appl. Nano Mater. 2021, 4, 2575-2582. [CrossRef]

168. Praoboon, N.; Siriket, S.; Taokaenchan, N.; Kuimalee, S.; Phaisansuthichol, S.; Pookmanee, P.; Satienperakul, S. Paper-based electrochemiluminescence device for the rapid estimation of trimethylamine in fish via the quenching effect of thioglycolic acid-capped cadmium selenide quantum dots. Food Chem. 2022, 366, 130590. [CrossRef]

169. Jia, Z.X.; Shi, C.; Wang, Y.B.; Yang, X.T.; Zhang, J.R.; Ji, Z.T. Nondestructive determination of salmon fillet freshness during storage at different temperatures by electronic nose system combined with radial basis function neural networks. Int. J. Food Sci. Technol. 2020, 55, 2080-2091. [CrossRef]

170. Chen, W.; Wang, Z.H.; Gu, S.; Wang, J.; Wang, Y.W.; Wei, Z.B. Hydrophobic amino-functionalized graphene oxide nanocomposite for aldehydes detection in fish fillets. Sens. Actuators B Chem. 2020, 306, 127579. [CrossRef]

171. Public Health and Environment. Available online: https://www.who.int/data/gho/data/themes/public-health-andenvironment (accessed on 3 December 2021).

172. Gardner, J.W.; Vincent, T.A. Electronic Noses for Well-Being: Breath Analysis and Energy Expenditure. Sensors 2016, $16,947$. [CrossRef]

173. Terrington, D.; Hayton, C.; Peel, A.; Fowler, S.; Wilson, A. Exhaled breath biomarkers in sarcoidosis: A systematic review. Eur. Respir. J. 2018, 52, PA3003. [CrossRef]

174. Peel, A.M.; Wilkinson, M.; Sinha, A.; Loke, Y.K.; Fowler, S.J.; Wilson, A.M. Volatile organic compounds associated with diagnosis and disease characteristics in asthma-A systematic review. Respir. Med. 2020, 169, 105984. [CrossRef]

175. Di Zazzo, L.; Magna, G.; Lucentini, M.; Stefanelli, M.; Paolesse, R.; Di Natale, C. Sensor-embedded face masks for detection of volatiles in breath: A proof of concept study. Chemosensors 2021, 9, 356. [CrossRef]

176. Li, D.S.; Shao, Y.Z.; Zhang, Q.; Qu, M.J.; Ping, J.F.; Fu, Y.Q.; Xie, J. A flexible virtual sensor array based on laser-induced graphene and MXene for detecting volatile organic compounds in human breath. Analyst 2021, 146, 5704-5713. [CrossRef] [PubMed]

177. Lee, B.M.; Eetemadi, A.; Tagkopoulos, I. Reduced Graphene Oxide-Metalloporphyrin Sensors for Human Breath Screening. Appl. Sci. 2021, 11, 11290. [CrossRef]

178. Tyagi, H.; Daulton, E.; Bannaga, A.S.; Arasaradnam, R.P.; Covington, J.A. Non-invasive detection and staging of colorectal cancer using a portable electronic nose. Sensors 2021, 21, 5440. [CrossRef]

179. Jalal, A.H.; Alam, F.; Roychoudhury, S.; Umasankar, Y.; Pala, N.; Bhansali, S. Prospects and challenges of volatile organic compound sensors in human healthcare. ACS Sens. 2018, 3, 1246-1263. [CrossRef]

180. Capuano, R.; Catini, A.; Paolesse, R.; Di Natale, C. Sensors for lung cancer diagnosis. J. Clin. Med. 2019, 8, 235. [CrossRef]

181. Sanchez-Vicente, C.; Santos, J.P.; Lozano, J.; Sayago, I.; Sanjurjo, J.L.; Azabal, A.; Ruiz-Valdepenas, S. Graphene-doped Tin oxide nanofibers and nanoribbons as gas sensors to detect biomarkers of different diseases through the breath. Sensors 2020, 20, 7223. [CrossRef] [PubMed]

182. Hanh, N.H.; Ngoc, T.M.; Duy, L.V.; Hung, C.M.; Duy, N.V.; Hoa, N.D. A comparative study on the VOCs gas sensing properties of $\mathrm{Zn}_{2} \mathrm{SnO}_{4}$ nanoparticles, hollow cubes, and hollow octahedra towards exhaled breath analysis. Sens. Actuators B Chem. 2021, 343, 130147. [CrossRef] 
183. Rodriguez-Aguilar, M.; de Leon-Martinez, L.D.; Gorocica-Rosete, P.; Perez-Padilla, R.; Dominguez-Reyes, C.A.; Tenorio-Torres, J.A.; Ornelas-Rebolledo, O.; Mehta, G.; Zamora-Mendoza, B.N.; Flores-Ramirez, R. Application of chemoresistive gas sensors and chemometric analysis to differentiate the fingerprints of global volatile organic compounds from diseases. Preliminary results of COPD, lung cancer and breast cancer. Clin. Chim. Acta 2021, 518, 83-92. [CrossRef] [PubMed]

184. Zaim, O.; Diouf, A.; El Bari, N.; Lagdali, N.; Benelbarhdadi, I.; Ajana, F.Z.; Llobet, E.; Bouchikhi, B. Comparative analysis of volatile organic compounds of breath and urine for distinguishing patients with liver cirrhosis from healthy controls by using electronic nose and voltammetric electronic tongue. Anal. Chim. Acta 2021, 1184, 339028. [CrossRef] [PubMed]

185. Wu, X.Y.; Wang, H.R.; Wang, J.H.; Wang, D.Z.; Shi, L.J.; Tian, X.; Sun, J.H. VOCs gas sensor based on MOFs derived porous $\mathrm{Au} @ \mathrm{Cr}_{2} \mathrm{O}_{3}-\mathrm{In}_{2} \mathrm{O}_{3}$ nanorods for breath analysis. Colloids Surf. A Physicochem. Eng. Asp. 2022, 632, 127752. [CrossRef]

186. Guo, W.W.; Huang, L.L.; Zhao, B.Y.; Gao, X.; Fan, Z.H.; Liu, X.Y.; He, Y.Z.; Zhang, J. Synthesis of the $\mathrm{ZnFe}_{2} \mathrm{O}_{4} / \mathrm{ZnSnO}_{3}$ nanocomposite and enhanced gas sensing performance to acetone. Sens. Actuators B Chem. 2021, 346, 130524. [CrossRef]

187. Yoon, J.W.; Lee, J.H. Toward breath analysis on a chip for disease diagnosis using semiconductor-based chemiresistors: Recent progress and future perspectives. Lab Chip 2017, 17, 3537-3557. [CrossRef]

188. Guo, W.W.; Huang, L.L.; Zhang, J.; He, Y.Z.; Zeng, W. Ni-doped $\mathrm{SnO}_{2} / \mathrm{g}-\mathrm{C}_{3} \mathrm{~N}_{4}$ nanocomposite with enhanced gas sensing performance for the eff;ective detection of acetone in diabetes diagnosis. Sens. Actuators B Chem. 2021, 334, 129666. [CrossRef]

189. Zhang, S.F.; Jiang, W.H.; Li, Y.W.; Yang, X.L.; Sun, P.; Liu, F.M.; Yan, X.; Gao, Y.; Liang, X.H.; Ma, J.; et al. Highly-sensitivity acetone sensors based on spinel-type oxide $\left(\mathrm{NiFe}_{2} \mathrm{O}_{4}\right)$ through optimization of porous structure. Sens. Actuators B Chem. 2019, 291, 266-274. [CrossRef]

190. Hu, J.; Yang, J.; Wang, W.D.; Xue, Y.; Sun, Y.J.; Li, P.W.; Lian, K.; Zhang, W.D.; Chen, L.; Shi, J.; et al. Synthesis and gas sensing properties of $\mathrm{NiO} / \mathrm{SnO}_{2}$ hierarchical structures toward ppb-level acetone detection. Mater. Res. Bull. 2018, 102, 294-303. [CrossRef]

191. Du, H.Y.; Li, X.G.; Yao, P.J.; Wang, J.; Sun, Y.H.; Dong, L. Zinc oxide coated Tin oxide nanofibers for improved selective acetone sensing. Nanomaterials 2018, 8, 509. [CrossRef]

192. Hu, J.; Zou, C.; Su, Y.J.; Li, M.; Yang, Z.; Ge, M.Y.; Zhang, Y.F. One-step synthesis of $2 \mathrm{D} \mathrm{C}_{3} \mathrm{~N}_{4}$-tin oxide gas sensors for enhanced acetone vapor detection. Sens. Actuators B Chem. 2017, 253, 641-651. [CrossRef]

193. Li, L.; Tan, J.F.; Dun, M.H.; Huang, X.T. Porous ZnFe2O4 nanorods with net-worked nanostructure for highly sensor response and fast response acetone gas sensor. Sens. Actuators B Chem. 2017, 248, 85-91. [CrossRef]

194. Ao, W.Y.; Fu, J.; Mao, X.; Kang, Q.H.; Ran, C.M.; Liu, Y.; Zhang, H.D.; Gao, Z.P.; Li, J.; Liu, G.Q.; et al. Microwave assisted preparation of activated carbon from biomass: A review. Renew. Sustain. Energy Rev. 2018, 92, 958-979. [CrossRef]

195. Cova, C.M.; Zuliani, A.; Santiago, A.R.P.; Caballero, A.; Munoz-Batista, M.J.; Luque, R. Microwave-assisted preparation of $\mathrm{Ag} / \mathrm{Ag}_{2} \mathrm{~S}$ carbon hybrid structures from pig bristles as efficient HER catalysts. J. Mater. Chem. A 2018, 6, 21516-21523. [CrossRef]

196. Zuliani, A.; Munoz-Batista, M.J.; Luque, R. Microwave-assisted valorization of pig bristles: Towards visible light photocatalytic chalcocite composites. Green Chem. 2018, 20, 3001-3007. [CrossRef]

197. Sun, X.H.; Shao, K.; Wang, T. Detection of volatile organic compounds (VOCs) from exhaled breath as noninvasive methods for cancer diagnosis. Anal. Bioanal. Chem. 2016, 408, 2759-2780. [CrossRef] [PubMed]

198. Hakim, M.; Broza, Y.Y.; Barash, O.; Peled, N.; Phillips, M.; Amann, A.; Haick, H. Volatile organic compounds of lung cancer and possible biochemical pathways. Chem. Rev. 2012, 112, 5949-5966. [CrossRef]

199. Behera, B.; Joshi, R.; Vishnu, G.K.A.; Bhalerao, S.; Pandya, H.J. Electronic nose: A non-invasive technology for breath analysis of diabetes and lung cancer patients. J. Breath Res. 2019, 13, 024001. [CrossRef]

200. Tripathi, K.M.; Sachan, A.; Castro, M.; Choudhary, V.; Sonkar, S.K.; Feller, J.F. Green carbon nanostructured quantum resistive sensors to detect volatile biomarkers. Sustain. Mater. Technol. 2018, 16, 1-11. [CrossRef]

201. Hassan, K.; Hossain, R.; Farzana, R.; Sahajwalla, V. Microrecycled zinc oxide nanoparticles (ZnO NP) recovered from spent Zn-C batteries for VOC detection using ZnO sensor. Anal. Chim. Acta 2021, 1165, 338563. [CrossRef]

202. Zito, C.A.; Perfecto, T.M.; Oliveira, T.N.T.; Volanti, D.P. Bicone-like ZnO structure as high-performance butanone sensor. Mater Lett. 2018, 223, 142-145. [CrossRef]

203. Pu, J.Y.; Kentala, K.; Dickinson, B.C. Multidimensional control of Cas9 by evolved RNA polymerase-based biosensors. ACS Chem. Biol. 2018, 13, 431-437. [CrossRef] [PubMed]

204. Xie, S.Y.; Ji, Z.R.; Suo, T.Y.; Li, B.Z.; Zhang, X. Advancing sensing technology with CRISPR: From the detection of nucleic acids to a broad range of analytes e A review. Anal. Chim. Acta 2021, 1185, 338848. [CrossRef] [PubMed]

205. Baracu, A.M.; Gugoasa, L.A.D. Review-recent advances in microfabrication, design and applications of amperometric sensors and biosensors. J. Electrochem. Soc. 2021, 168, 037503. [CrossRef]

206. Kleinekorte, J.; Fleitmann, L.; Bachmann, M.; Katelhon, A.; Barbosa-Povoa, A.; von der Assen, N.; Bardow, A. Life cycle assessment for the design of chemical processes, products, and supply chains. Annu. Rev. Chem. Biomol. Eng. 2020, 11, 203-233. [CrossRef] [PubMed] 